Full Length Article

\title{
Conceptual model of the Gülbahçe geothermal system, Western Anatolia, Turkey: Based on structural and hydrogeochemical data
}

\author{
Taygun Uzelli a , Alper Baba ${ }^{\mathrm{b}, *}$, Gamze Gül Mungan ${ }^{\mathrm{b}}$, R. Kadir Dirik ${ }^{\mathrm{a}}$, Hasan Sözbilir ${ }^{\mathrm{c}}$ \\ a Hacettepe University, Department of Geological Engineering, 06800, Ankara, Turkey \\ b Izmir Institute of Technology, Geothermal Energy Research and Application Center, 35430, Izmir, Turkey \\ c Dokuz Eylül University, Earthquake Research and Application Center, 35100, Izmir, Turkey
}

\section{A R T I C L E I N F O}

\section{Article history:}

Received 20 March 2016

Received in revised form 10 March 2017

Accepted 16 March 2017

Available online 22 March 2017

\section{Keywords:}

Geothermal fluid

Gülbahçe fault zone

Negative flower structure

Isotope

High salinity

\begin{abstract}
A B S T R A C T
The Gülbahçe Geothermal Field is located on the eastern margin of the Karaburun Peninsula, about $45 \mathrm{~km}$ from the city of Izmir, western Anatolia, Turkey. The stratigraphy of the study area is represented by a Miocene volcano-sedimentary succession, including several sedimentary and volcanic units. These units overlie the basement rocks of the Karaburun Platform and Bornova Flysch Zone which consist of sandstones, shales and carbonate blocks. These rock units are cut and deformed by a series of NW-SE- to NE-SW-trending faults, extending from Sığacık Bay to Gülbahçe Bay. Structural studies suggest that while most of the geothermal systems in western Anatolia are controlled by normal faults, the geothermal system at Gülbahçe is controlled by a strike-slip dominated shear zone, previously named the İmir-Balıkesir Transfer Zone. Along the fault zone, associations of active fault segments accommodate deep circulation of hydrothermally modified sea water, and thus the resulting negative flower structure is the primary control mechanism for the geothermal system.

Hydrogeochemical properties of the field show that surface temperature of fluid ranges from 30 to $34^{\circ} \mathrm{C}$. Geothermal fluids in Gülbahçe have high salinity (EC>34 mS/cm) and low enthalpy. Piper and Schoeller diagrams indicate that geothermal fluid is in the $\mathrm{NaCl}$ facies. Chemical geothermometers suggest that the reservoir temperature is around $53-136^{\circ} \mathrm{C}$. The isotopic data (oxygen-18, deuterium and tritium) suggest that geothermal fluids are formed by local recharge and deep circulation of sea water.
\end{abstract}

(c) 2017 Elsevier Ltd. All rights reserved.

\section{Introduction}

Geological framework has been an important focus for interpreting and finding suitable locations for geothermal systems without any surface manifestation. Stratigraphic sequence, cap rock, reservoir rock, permeability and porosity, fluid dynamics, fault-fracture relations to regional and/or local stress regime, and heat flow in lithosphere are requisite parameters to develop a favorable geothermal system.

From the global view point, plate tectonics control the thermal conditions in the crust and geothermal systems are shaped by largescale movements of plates. Likewise, geothermal systems in Turkey fall within the active Alpine-Himalayan Fold and Thrust Belt where the collision of African and Eurasian plates and also the closure of the Tethys Ocean occurs today (Bozkurt, 2001). As part of the Alpine-Himalayan Fold and Thrust Belt, the Aegean Sea, Greece, FYR

\footnotetext{
* Corresponding author.

E-mail addresses: alperbaba@iyte.edu.tr, alperbaba33@yahoo.com (A. Baba).
}

of Macedonia, Bulgaria, Albania and West Anatolia are located in the Aegean Extensional Province (AEP), which is one of the most rapidly extending and deforming areas on the continent today (Roberts and Jackson, 1991; Bozkurt, 2001; Bozkurt and Mitwede, 2001).

Deformation due to tectonism causes $\mathrm{N}-\mathrm{S}$ extension and forms normal faulting with the development of many E-W oriented continental basins in the AEP (Şengör et al., 1985; Yilmaz et al., 2000). The graben systems and major faults accompanied by young volcanism form abundant geothermal areas in tectonically-active western Anatolia (Bozkurt, 2001). Geothermal springs in western AEP roughly parallel the trends of the graben-bounding faults of the Menderes Metamorphic Core Complex (MMCC), young volcanism and generally hydrothermally altered areas (Şimsek, 1997; Mutlu and Güleç, 1998; Simsek et al., 2002; Baba and Ármannsson, 2006; Baba and Sözbilir, 2012) (Fig. 1(a)).

Fig. 1 shows the geological map of western Anatolia with the main graben-horst structures which are limited by a major strikeslip shear zone at the western boundary of the region where the study area is located. The strike-slip shear zone, namely the İzmirBalıkesir Transfer Zone (IBTZ), previously acted as a deep crustal 


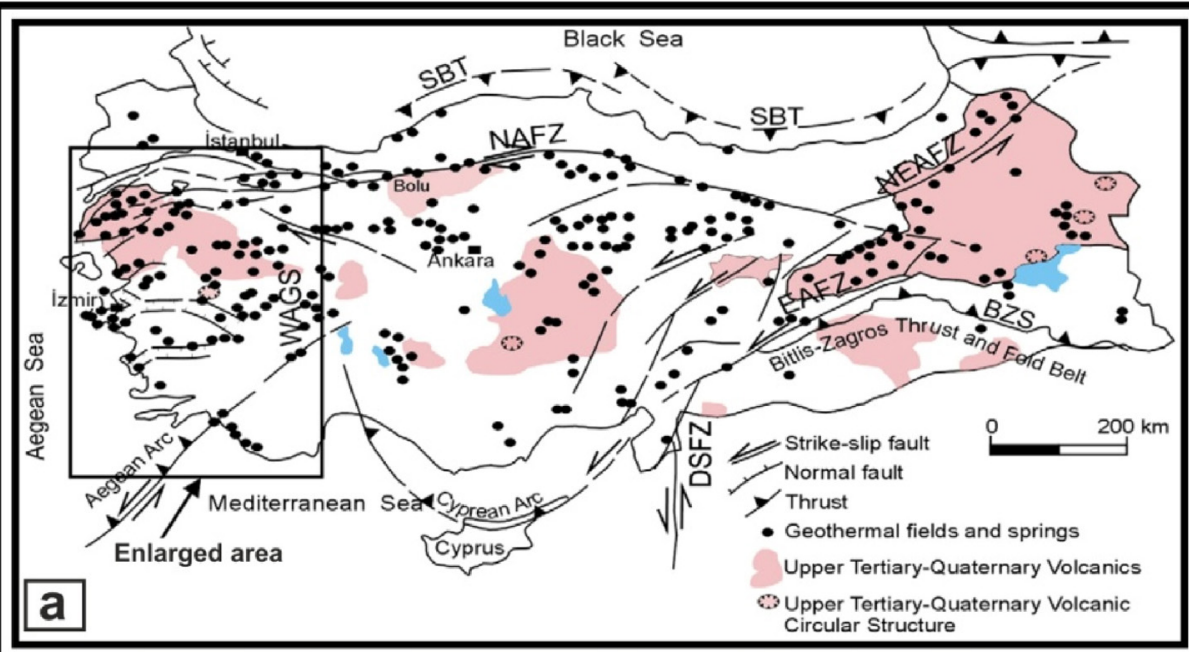

\section{EXPLANATIONS}

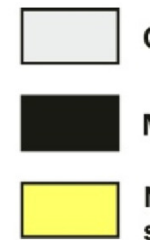

Quaternary alluvium

Miocene Granitoids

Neogene volcano-

sedimentary basins

Oligo-Miocene

Molasse Basins

Bornova flysch zone

Karaburun platform

NTAKATE Upper Tertiary-Quat
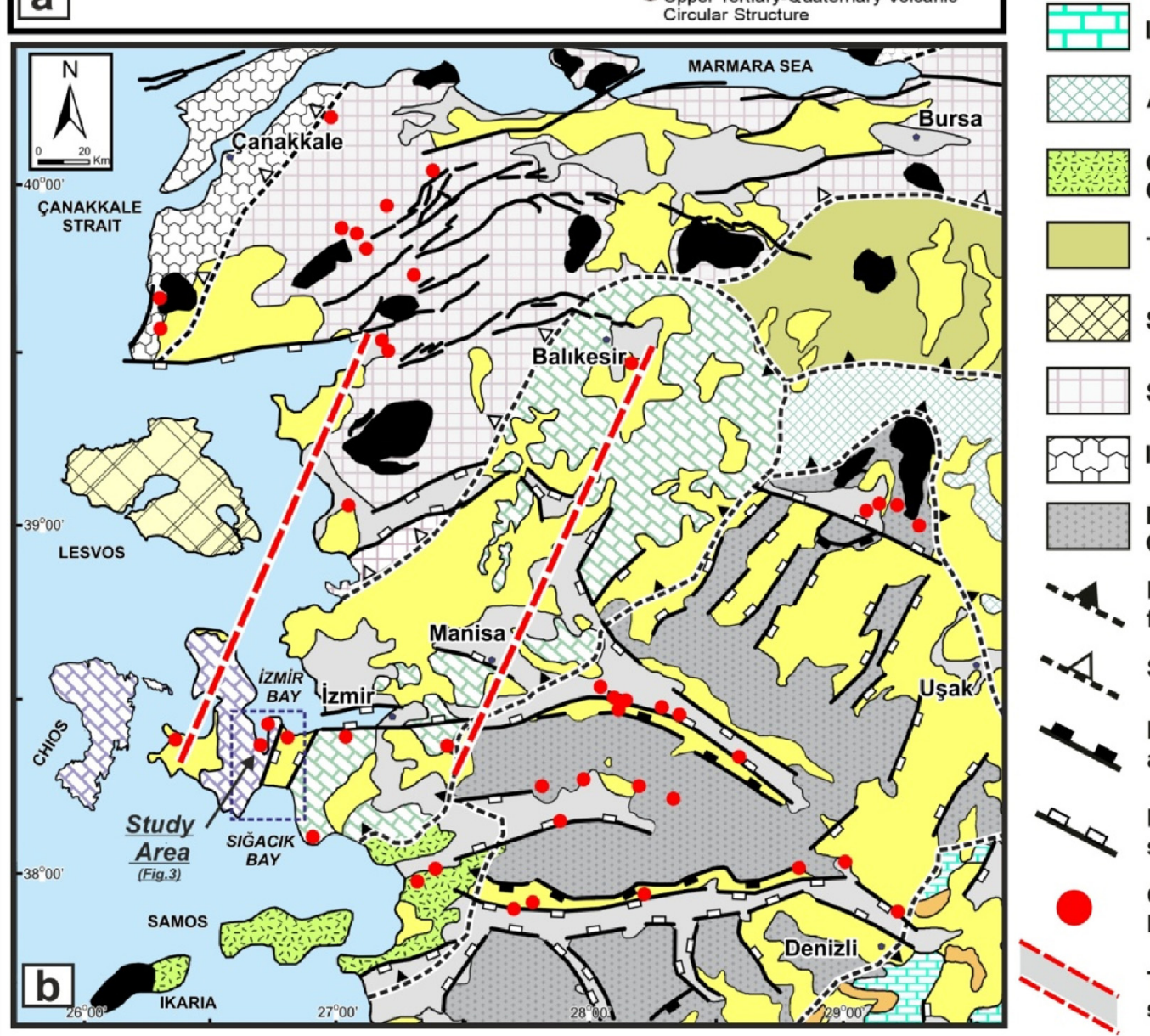

Lycian Nappes

87 Afyon zone

Cycladic Core

Complex

Tavşanlı zone

\section{Subpalegonian}

Sakarya zone

Istranca Massif

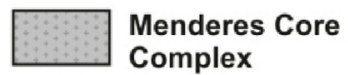

Complex

Major thrust

fault

- Suture zone

Detachment fault
and shear zone

Normal/Oblique

slip fault

Geothermal

Field

The zone of strikeslip faulting

Fig. 1. (a) Tectonic map of the eastern Mediterranean region showing main neotectonic structures and distribution of geothermal areas of Turkey (compiled from; Şimsek et al., 2002; Yiğitbaş et al., 2004; Baba and Armannsson, 2006; Baba and Sözbilir, 2012) (SBT, Southern Black Sea Thrust; NAFZ, North Anatolian Fault Zone; NEAFZ, Northeast Anatolian Fault Zone; EAFZ, Eastern Anatolian Fault Zone; WAGS, Western Anatolian Graben System; DSF, Dead Sea Fault Zone; BZS, Bitlis-Zagros Suture) (b) Simplified tectonic map of western Anatolia with known geothermal fields (after Sözbilir et al., 2011) with the zone of strike-slip faulting.

transform fault zone during the Late Cretaceous, while during the Neogene stress regimes in the region changed and it was controlled by transtensional stresses (Okay and Siyako, 1993; Okay et al., 1996; Ring et al., 1999; Sözbilir et al., 2008; Sözbilir et al., 2011; Özkaymak and Sözbilir, 2008; Uzel and Sözbilir, 2008; Uzel et al., 2012, 2013, 2015; Özkaymak et al., 2011). The transtensional tectonic regime also controls the deformation of pre-Neogene basement rock units, Miocene volcano-sedimentary units and Quaternary units (Fig. 1(b)).
The NE-SW-trending IBTZ includes strike-slip faults that generally have N-S, NE-SW and NW-SE orientations. Some of the strike-slip faults form geothermal systems in the region between Balıkesir and İzmir cities. The southern part of the IBTZ, İzmir and its surroundings, contains important geothermal fields such as Balçova, Seferihisar, Dikili, Bergama, Özbek-Ilıksu and Çeşme, and also there are many hot water springs on Karaburun Peninsula. The study area is located on the eastern margin of Karaburun Peninsula 
and is about $45 \mathrm{~km}$ from the city of İmir in the south-west coast of Gülbahçe Bay (Fig. 1(b)). The Gülbahçe region has two important hot-water springs with geothermal origin; Gülbahçe and Ilıksu springs. Ilıksu geothermal spring is located north-east of Gülbahçe Bay and approximately 6 kilometers from the northern border of our study area. These two geothermal springs are both tectonically controlled and have direct connection with sea-water intrusion.

This study presents the results of a multidisciplinary approach aimed at understanding the relationship between tectonic setting and geothermal systems in the region and to evaluate hydrogeochemical features of geothermal fluid in this region.

\section{Geological setting}

\subsection{Stratigraphy}

The rock units exposed in the study area are divided into two main groups for simplification in the study: basement and cover rocks. The basement is made up of Triassic-Jurassic rocks of Karaburun Platform Carbonates and Upper Cretaceous to Paleocene rocks of Bornova Flysch Zone (BFZ). The unconformably-overlying cover rocks are Miocene volcano-sedimentary units and Quaternary deposits. Basement rocks outcrop on the south-eastern side of the study area and are bounded by the Gülbahçe Fault Zone (GFZ). Regionally, cover rocks were deposited in Urla Basin, and were accompanied by Miocene volcanic units which are the products of two-phase volcanic activity (Fig. 2 and 3).

\subsubsection{Basement rocks: Pre-Miocene units}

The oldest basement rock units in the study area are carbonates of the Karaburun Platform which is also called the Karaburun Belt in the literature (Erdoğan, 1990; Kozur, 1997; Robertson and Pickett, 2000). The Karaburun Platform is one of the most important tectonic belts west of the MMCC and the BFZ. Rocks of the Karaburun Platform are closely related to evolution of the Tethyan Ocean (Erdoğan, 1990).

In the study area, Karaburun Platform is represented by two formations: Nohutalan and Güvercinlik Formations. The latter is made up of Carnian-Rhaetian oolitic limestones with Megalodon, and green, yellow to red siltstone, sandstone and pisolitic conglomerate with iron and bauxite. Also in some areas the formation has light gray laminated dolomite and white dolomitic limestones (Lechner et al., 1967; Brinkmann, 1966; Brinkmann et al., 1972; Çakmakoğlu and Bilgin, 2006). These shallow marine limestones have a widespread surface and subsurface distribution in the area and are gradational with the Nohutalan Formation (Fig. 2). The Nohutalan Formation is a uniform unit with limestones, dolomitic limestones and limestone with Cladocoropsis sp. fossils (Brinkmann et al., 1972). The formation is Liassic-Malm in age, gray in color, 500 thick $\mathrm{m}$ and was deposited in shallow marine reef environment (Çakmakoğlu and Bilgin, 2006).

The BFZ is a tectonic belt lying between the MMCC and Karaburun Platform. The BFZ, which is also known as the "Bornova complex" (Erdoğan, 1990), has a deformed Upper CretaceousPaleocene aged matrix. The matrix contains different blocks of various lithologies; Mesozoic limestones, radiolarites, ultrabasic rocks, and altered basic volcanic rocks. The BFZ is unconformably overlain by the Miocene and Quaternary cover units.

\subsubsection{Cover rocks: Miocene and quaternary units}

The Miocene volcano-sedimentary unit is composed of conglomerates, sandstone and mudstone alternations, followed by yellow/white thin bedded and weathered fresh-water limestones. During deposition, two volcanic units were emplaced in the study area in the early Miocene. In the western part of the study area;
Kocadağ volcanics comprise lavas, pyroclastic blocks and ash flow deposits. The andesitic lavas are characterized by plagioclase and brown amphibole phenocrysts in a glassy matrix (Helvaci et al., 2009). The unit interfingers with the Miocene volcano-sedimentary units and was previously dated as 16.6 and $17.3 \mathrm{Ma}$ (K-Ar ages) by Borsi et al. (1972) (Fig. 2). In the east of the study area, Urla volcanics were emplaced with fine grained rhyolitic lavas and porphyritic domes with trachyte-like porphyritic rhyolite domes (Kaya, 1981; Helvaci et al., 2009). The unit cuts and unconformably overlies the limestones of the Miocene volcano-sedimentary succession. The Urla volcanics have been dated by Borsi et al. (1972) to 11.7 and 11.9 $\mathrm{Ma}$ (K-Ar ages).

Higher in the sequence the Miocene volcano-sedimentary unit contains thick-bedded white limestones and brown/gray mudstone, marl, interlayers and limestones crop out extensively in south-eastern parts of Gülbahçe Bay (Kaya, 1981). The Miocene deposits are unconformably overlain by Quaternary deposits; Pleistocene Ballıkaya conglomerate, and Holocene deposits. In Gülbahçe sub-basin, Pleistocene conglomerates have widespread distribution and thicken towards Ballıkaya Hill, where it exceeds $40-45 \mathrm{~m}$. The unit has clast-supported texture and alternating gravel grains of several different rock types interbedded with claystone-mudstone-sandstone layers. The facies of the unit is interpreted as channel-fill conglomerate. The unconformablyoverlying Holocene units are generally alluvial fan/plain deposits, colluvial deposits near steep slopes of fault scarps and fan/delta to shallow marine deposits along the shoreline of Gülbahçe Bay.

\subsection{Tectonic framework of the region}

There are close relationships between tectonic framework and hydrogeochemical properties in local geothermal systems such as Gülbahçe. More specifically, where the geothermal system is controlled by secondary permeability, the study of the fracture, joint and fault network is important to understand unknown flow pathways in hydrothermal systems. Therefore the geothermal system was investigated with structural data for better understanding of the geometry of the system.

The Gülbahçe geothermal field is located on the western margin of Urla basin, which is a depositional environment between Karaburun Platform and the BFZ. Landforms in Urla Basin are mainly controlled by Gülbahçe and Seferihisar Fault Zones (SFZ), at the western and eastern margins of the basin, respectively. Among them, Demircili-Yağcılar (DYFZ) and Kuşçular-Urla (KUFZ) fault zones extend between Gülbahçe Bay and Sığacık Bay, and are possibly under the control of strike-slip faulting of the IBTZ (Fig. 3). Due to the combination of these fault zones, four different small sub-basins have been formed in Urla Basin; these are İçmeler, Turasan, Kuşçular and Gülbahçe sub-basins (Fig. 3). The Gülbahçe sub-basin is located on the south-west coast of Gülbahçe Bay and is tectonically bordered by approximately N-S-trending faults that are consistent with its transtensional origin. The N-Strending sub-basin is about $2 \mathrm{~km}$ wide and $6 \mathrm{~km}$ long and contains up to $700-800 \mathrm{~m}$ thick Miocene volcano-sedimentary units and Pleistocene conglomerates (Pamukçu et al., 2014).

The Turasan, Kuşçular and İçmeler sub-basins are also tectonically controlled and bordered by NW-SE- and N-S-trending faults. These three adjacent basins contain recent alluvium and Miocene volcano-sedimentary units near the surface. İçmeler and Gülbahçe sub-basins are separated by a narrow ridge made up of basement limestones. The ridge could possibly have formed by uplifting of basement rocks similar to the formation of the Turasan, Kuşçular and İçmeler sub-basins, which are separated by uplifted limestone outcrops of Miocene units (Fig. 4). 


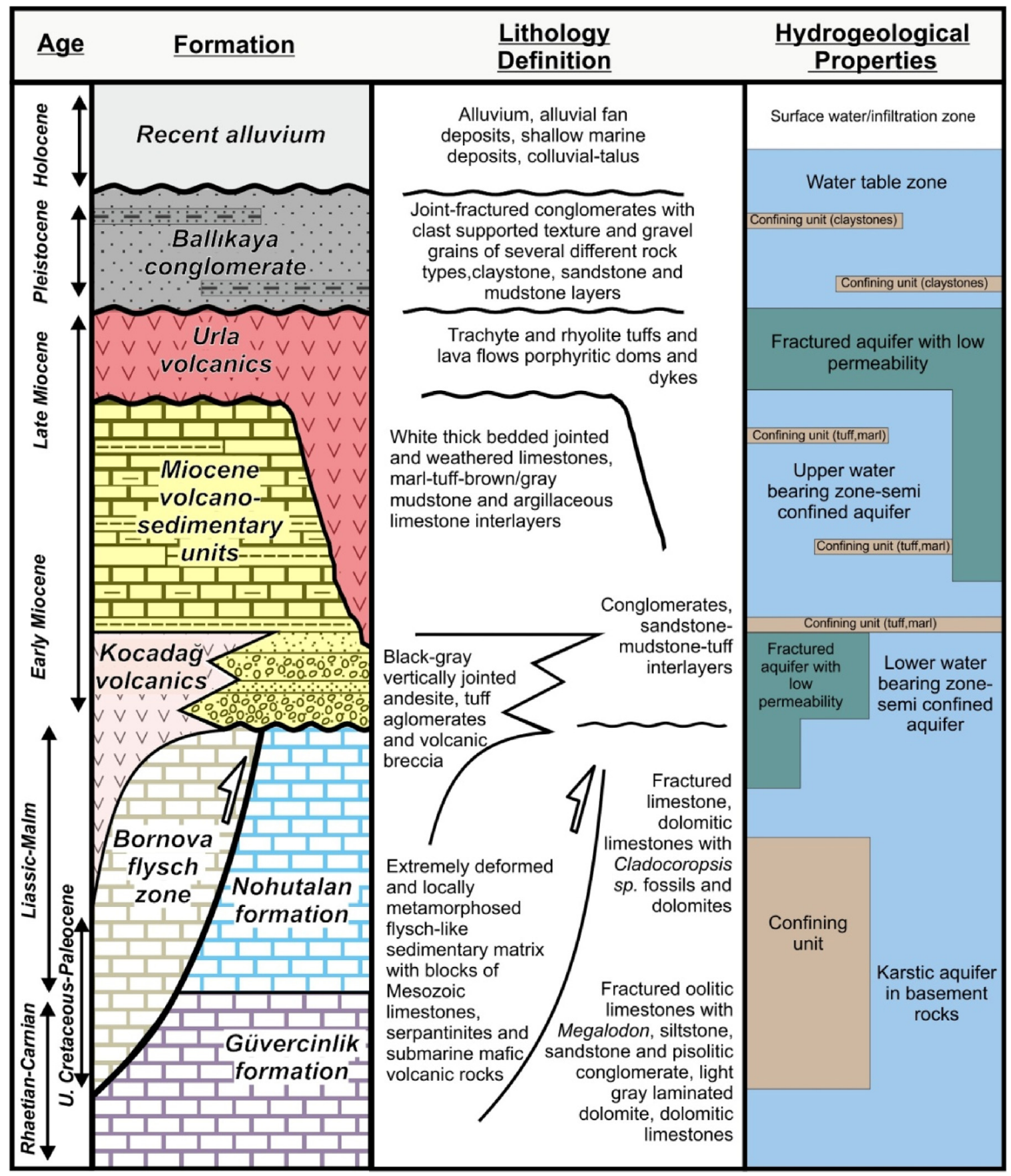

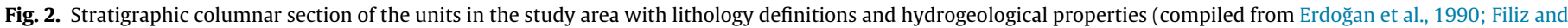
Tarcan, 1990; Çakmakoğlu and Bilgin, 2006; Helvacı et al., 2009 and this study).

\subsection{Structural geology}

The dominant structural trend in the Gülbahçe area is N-S and many faults are mapped as parts of fault zones and individual segments in this study. Kinematic studies were carried out at nine different stations. Data was also collected from joints (Station 6) near the geothermal spring (Fig. 4). All of the faults and joints are grouped under three headings based on their strikes; N-S, NE-SW and NW-SE trending faults.

\subsection{1. $N$-S-trending faults}

The GFZ starts at the south with two parallel segments that can be followed along mountain ranges for nearly $10 \mathrm{~km}$. Fault seg- ments enter Gülbahçe sub-basin near Sögütköy River and form the boundaries of the basin. Although segments have strike-slip character in the south, they show oblique-slip to normal slip character where they enter Gülbahçe sub-basin in the north. The Söğütköy fault (Station 8), which takes its name from Sögütköy stream, has approximately $\mathrm{N}-\mathrm{S}$ strike and steeply dips towards the $\mathrm{W}$, separates basement units from Quaternary deposits and also controls the morphology of streams around the GGF (Fig. 4).

The other important structure is the N-S oriented normal fault segment (Station 1) with 5-6 km length. The fault plane can be observed in the Gülbahçe sub-basin around the eastern boundary of the Kocadağ volcanics. Near Ballıkaya Hill, it jumps to west, where talus breccias cover the fault plane and then continues 


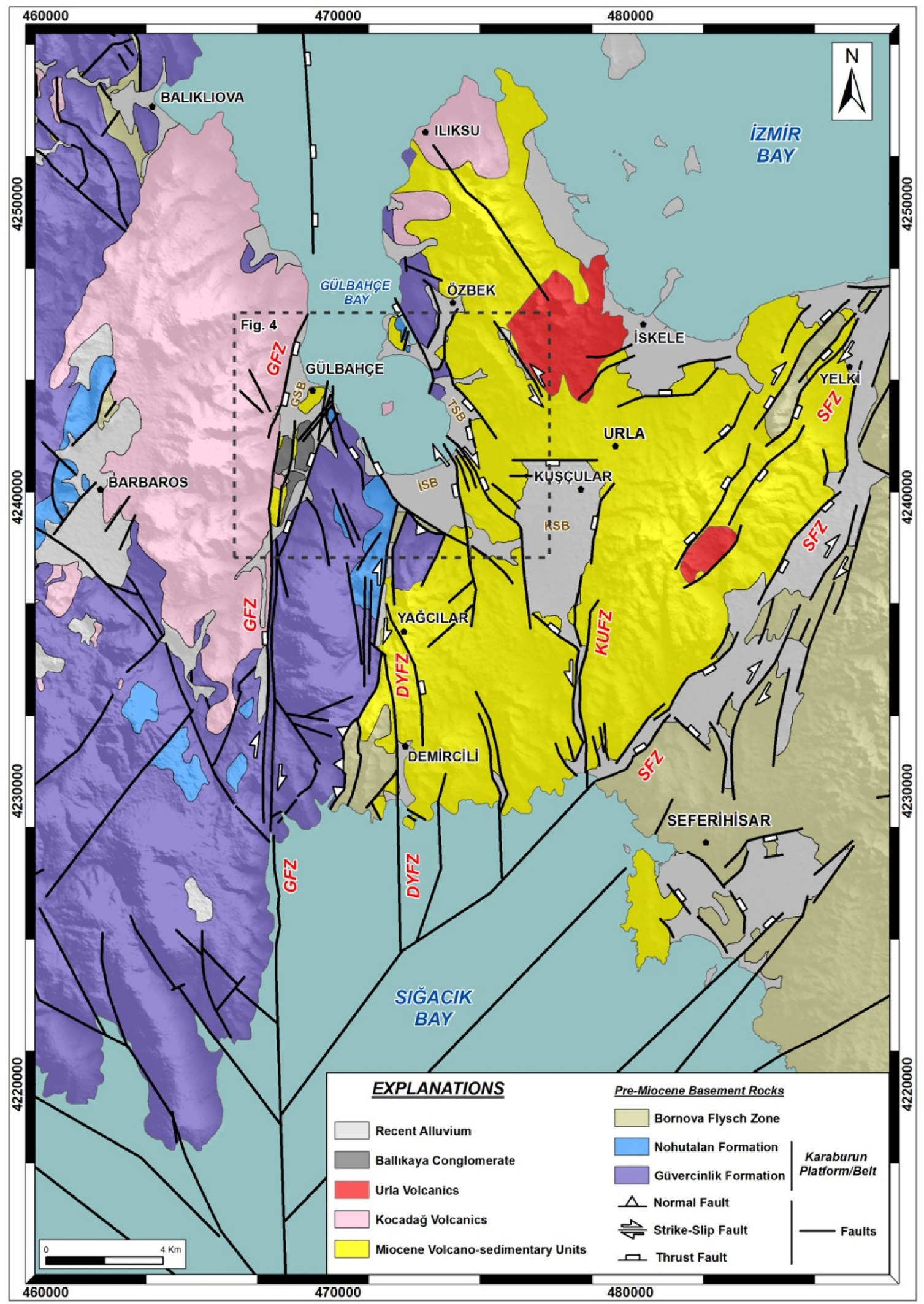

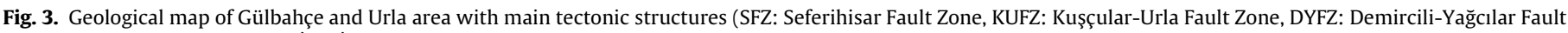

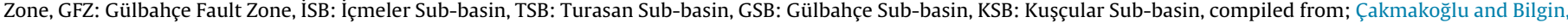
2006; Helvaci et al., 2009; Uzel et al., 2012, 2013 and this study). 


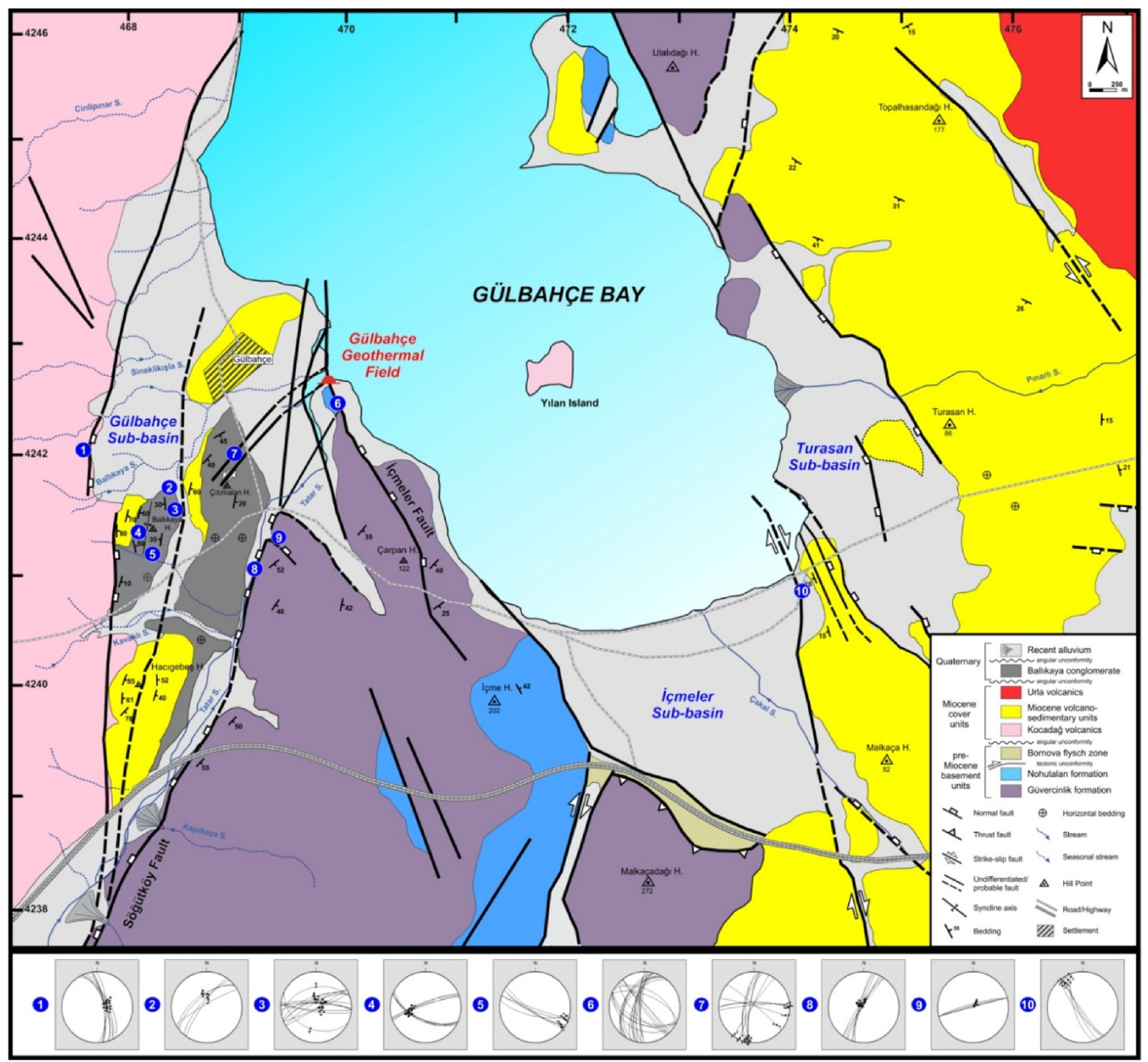

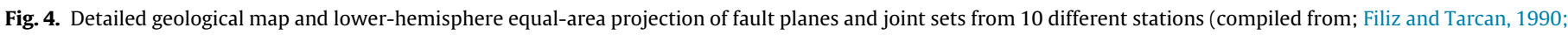
Çakmakoğlu and Bilgin, 2006; and this work).

to the north before disappearing below the sea in Gülbahçe Bay (Figs. 4 and 5). This step-over structure formed a possible relayramp geometry which is very important for geothermal fluids rising through geothermal systems.

According to magnetotelluric surveys (Pamukçu et al., 2014), morphological interpretations and satellite photos, there is a strong possibility of the existence of another fault between Ballıkaya and Çıtırlialan Hills. It is also parallel to known fault segments and mapped as a probable fault in this study. In addition, as seen from Stations 3, 4 and 5; we detected many small E-W striking normal/oblique slip normal faults between Gülbahçe and İçmeler faults and around Ballıkaya Hill. These faults reflect the extensional faulting related to the transtensional strike-slip regime in the Gülbahçe sub-basin. The faults of this set are well exposed around the study area. For example; there is another major N-S striking fault segment located between İçmeler and Malkaçadağı Hills. That fault is a continuation of the DYFZ, cutting and displacing basement rocks with right-lateral strike-slip character (Fig. 4). Also, there are several antithetic and synthetic faults that cut mainly limestones of
Nohutalan and Güvercinlik formations. The general trend of these small scale faults and joint-sets appear to be N-S directed but in local areas detached limestone blocks have distinct jointing and deformation pattern.

\subsubsection{NE-SW-trending faults}

The NE-SW-trending faults are mainly strike-slip faults, with mean strike of $\mathrm{N} 30^{\circ} \mathrm{E}$ observed in different parts of the study area. Northern segments of the GFZ and the DYFZ may be considered as part of this fault classification. In addition, we mapped two parallel active strike-slip faults (Station 7) extending between Çıtırlıalan Hill and GGF, as shown in Fig. 4. The observed lengths of these faults are approximately $1.8 \mathrm{~km}$ and they cut Pleistocene Ballıkaya conglomerate and recent alluvium (Fig. 6). Faults have N10-25 ${ }^{\circ}$ strikes and high dip angles with nearly horizontal slicken sided fault planes. Subsidiary antithetic Riedel shear fractures observed around the main fault are shown on lower hemisphere equal area projection with main fault plane data from Station 7. The NE-SW strike-slip fault is possibly responsible for sea-water intrusion into 


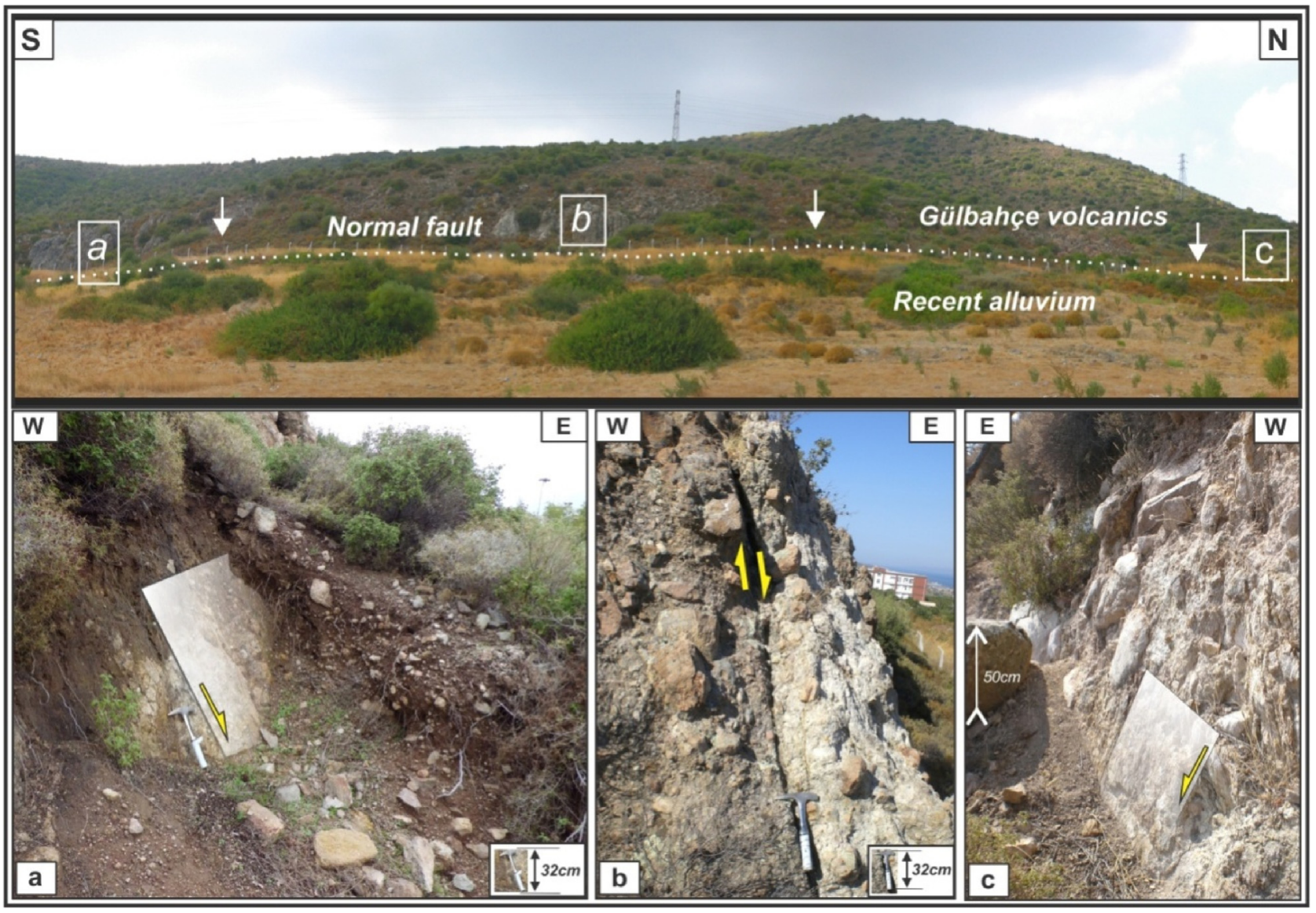

Fig. 5. Field photos taken from normal fault segment (Station 1) on the contact of Kocadağ volcanics with recent talus/alluvium deposits.

Gülbahçe sub-basin, and also affects the morphology and strength of barrier units around the GGF, where the Sögütköy stream discharges into Gülbahçe Bay.

\subsubsection{NW-SE-trending faults}

The NW-SE-trending fault segments are basin-bounding structures of Turasan and İçmeler sub-basins. The İçmeler fault, also called the Ilıca fault in previous works (Çetiner et al., 2000; Çakmakoğlu and Bilgin, 2006), is one of the faults that bounds the western margin of İçmeler basin, cutting and displacing Güvercinlik limestones. İçmeler fault has a normal fault character; footwall block is on the SW side of fault plane, thus the northern block slid down relative to footwall developing low relief topography. Also the fault plane in massive limestones could act as a hydrogeological barrier, with sea-water intrusion into the geothermal system possibly limited under this condition and the present shoreline is shaped by İçmeler fault. Sea-water intrusion can be seen locally in the north-eastern part of Gülbahçe sub-basin where the NWSE striking fault segments intersect with NE-SW striking İçmeler Fault. Eastern boundary of the İçmeler sub-basin is under control of another NW-SE-trending right lateral strike-slip fault (Station 10) with minor dip slip component. In the same area, the Miocene limestone outcrops between Içcmeler and Turasan sub-basins are deformed by four parallel faults with normal fault character as detected from block movements of limestone-marl-tuff layers.

The Turasan sub-basin is bounded by NW-SE-trending normal faults which caused significant changes in topography. However, fault planes cannot be seen directly in the field because of cover units, alluvium and settlements. For that reason, air-photos, satellite images, drainage patterns and 3-D digital elevation models of the area were used for detection of faults. Likewise, at the bound- ary between Urla volcanics with Miocene and Quaternary units, another NW-SE-trending left-lateral strike-slip fault was detected by analyzing drainage pattern anomalies and satellite images.

\section{Hydrogeology and hydrogeochemistry of geothermal fluid}

\subsection{Hydrogeological properties of study area}

Knowledge of the stratigraphy, permeability and fracture pattern of the study area are fundamental factors to model the geothermal system. The hydrogeological properties of the study area were reviewed based on the above described stratigraphic units with their hydrogeological role. The study indicates that faults and fractures have created predominantly N-S, NE-SW and NW-SE oriented apertures and pathways for water circulation. The water from precipitation, surface run-off, stream-drainage water and sea water infiltrate through this intensely fractured system and feed the hydrothermal system.

Although not having primary porosity, limestones of the Nohutalan and Güvercinlik formations have karst features, fissures, faults, joint sets and open fractures that are the main factors controlling secondary permeability. The fracturing and jointing lead a secondary permeability with spacing generally between 10 and $45 \mathrm{~cm}$ and some variable openings so surface water could easily infiltrate through these units (Fig. 7(b)). When considering the size of the limestone outcropping in the region, discontinuities could control the recharge of hydrothermal fluids and limestones could become a reservoir for the geothermal system. Actually, there are many karstic springs such as İçmeler spring with $200 \mathrm{lt} / \mathrm{sec}$ flow rate that can be seen around the geothermal field (Fig. 8). 


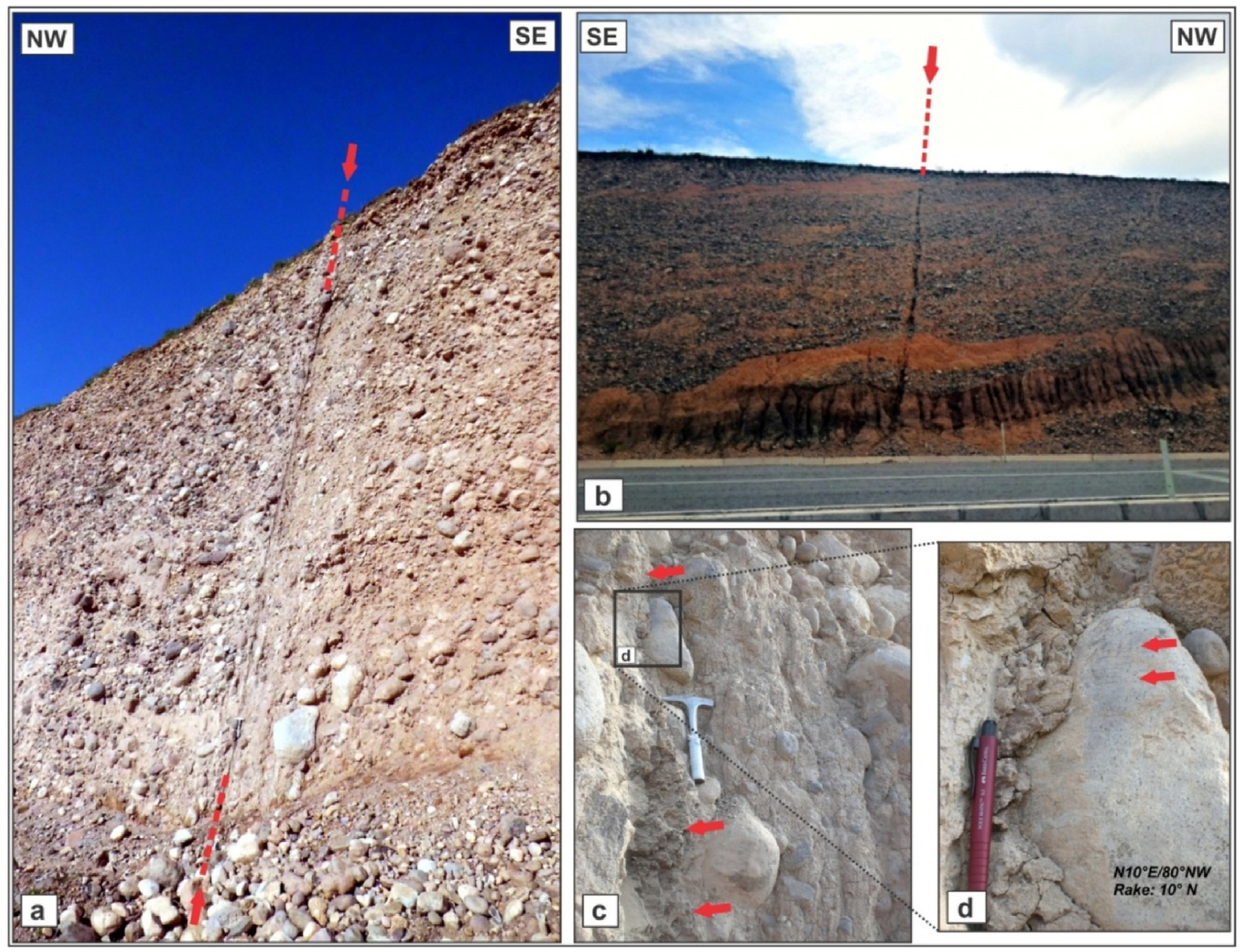

Fig. 6. Field photos of strike-slip faults from Station 7 on Ballıkaya conglomerate deposits.

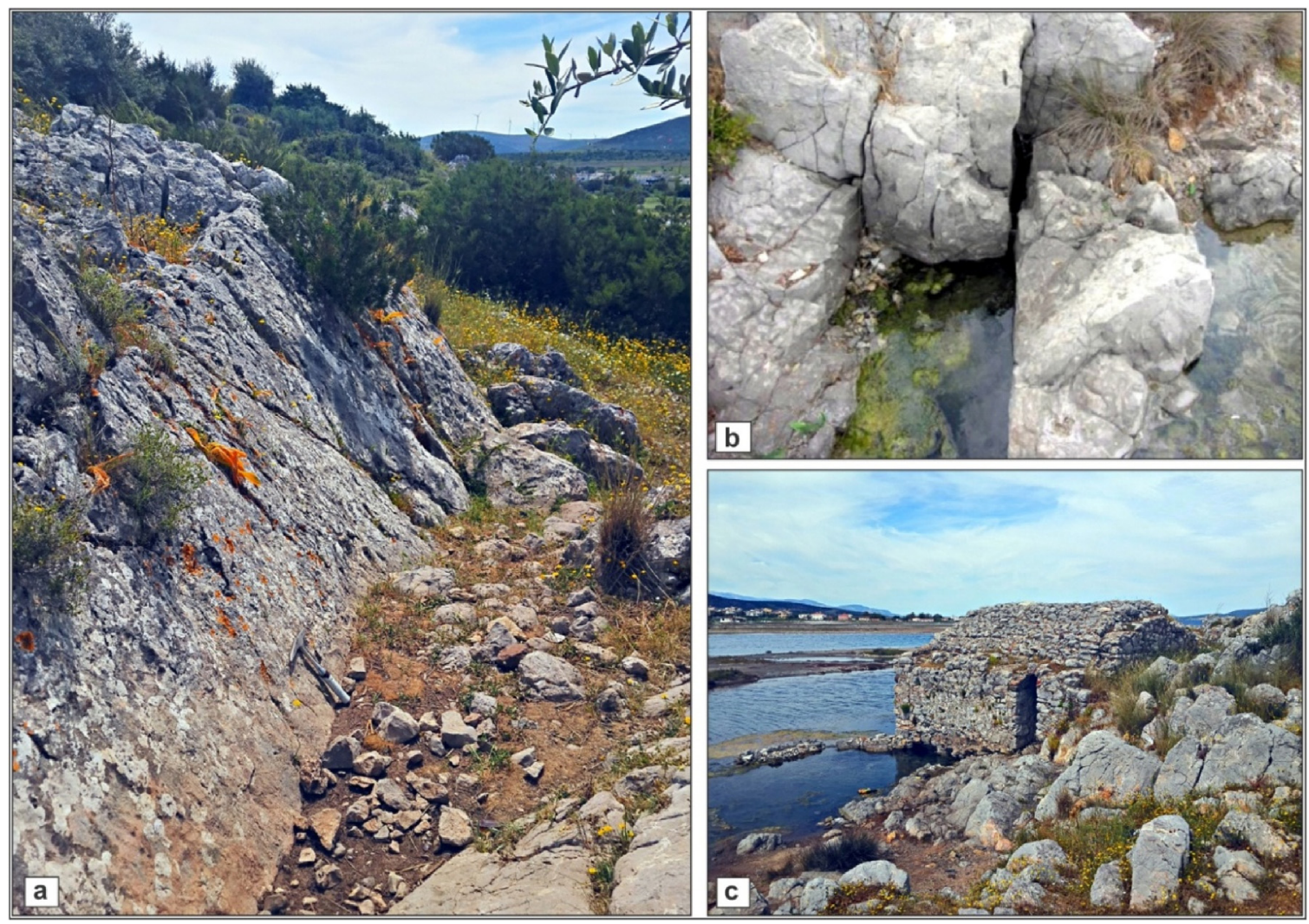

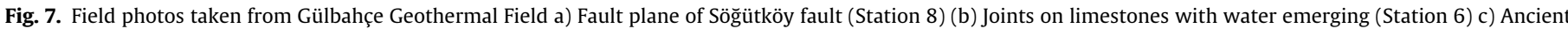
ruins of Roman bath nearby Gülbahçe hot-spring. 


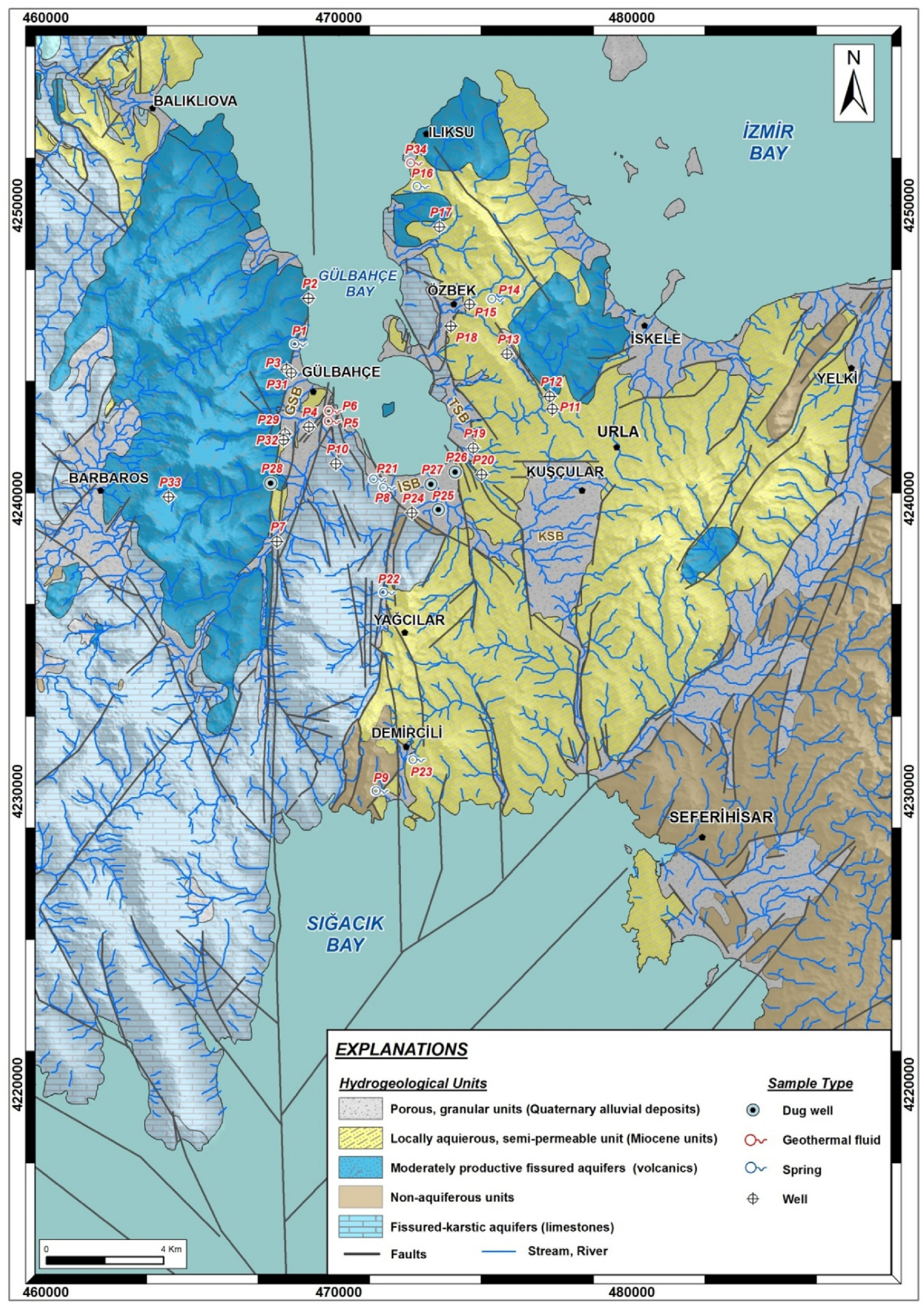

Fig. 8. Hydrogeological map of Gülbahçe and surrounding area with sample locations.

However, another basement unit, the Bornova flysch that is composed of sandstones, siltstones, shales, granodiorites, serpentinites, and diabase, has neither permeability nor porosity. Despite not having any primary porosity and permeability, fractures and underground deformation zones may allow water circulation. According to regional perspectives and absence of sufficient subsurface data, this unit is considered a hydrogeologically-confining, non-aquiferous unit. 
The Miocene volcano-sedimentary succession comprises volcanic and lacustrine units. The unit has variable permeability features due to lithology alternations such as claystone, sandstone, limestone, tuff and marl. The Miocene strata contain many layers, lenses of marl and volcanic tuffs with low hydraulic conductivity and they act as local confining units between upper and lower parts of the succession. The unit could not allow the rise of geothermal fluids through cover units by separating them from cool groundwater and sea-water in the geothermal system. Previous studies and drillings show that Miocene limestones have thickness of $250-300 \mathrm{~m}$ in this region. However, apart from basement, the Miocene limestones have limited extent near the GGF and generally crop out and cover wide areas around the eastern coast of Gülbahçe Bay. In this study, Miocene strata are considered a locally aqueous, water-bearing, semi-permeable unit.

The volcanic units existing in the study area have similar hydrogeological properties because of their lithological properties and structural frameworks. Primary porosity and permeability of Kocadağ volcanics are low because of matrix lithification of agglomerates, volcanic breccias and andesite lithology but secondary permeability is an important factor for water circulation. These volcanics have well-developed connected fracture networks, faults and vertical cooling joint sets. There are many low-flowing springs and drilling up to $100-120 \mathrm{~m}$ with flow rates around $1-3 \mathrm{lt} / \mathrm{sec}$. The Kocadağ volcanics are considered a moderately productive, fractured, fissured aquifer in this study. Lavas and tuff layers of the younger volcanic unit, Urla volcanics, are impervious and considered as hydrogeologically confined units. Cooling joints can be a good factor for second permeability within the Urla volcanics, but closed fractures and thick clayey fault breccias cause low secondary permeability in local areas. Due to surface conditions, volcanic rocks are intensely deformed and altered so they became more convenient for water circulation. As a result of discontinuities, the Urla volcanic unit is considered a moderately productive, fractured, fissured aquifer similar to Kocadağ volcanics.

Recent alluvium deposits are exposed around Gülbahçe and İçmeler basins, the shoreline of Gülbahçe Bay and in topographically low stream areas. The unit comprises alluvial and fluvial sediments consisting of gravel, sand and clay layers. Alluvium has a thickness of nearly $30 \mathrm{~m}$ in Gülbahçe sub-basin and is thicker around the İçmeler sub-basin. There are many dug and drilled wells located on alluvial deposits and these wells are very important due to being a water supply for the Urla region. Recent deposits seem hydrogeologically porous and granular units. Additionally, despite having good permeability and porosity, near sea-level areas, salinity and sea-water intrusion is an important issue for all water-supply wells located in recent deposits.

\subsection{Hydrogeochemical properties of the study area}

\subsubsection{Material and methods}

For the investigation and comparison of hydrogeochemical characteristics, three geothermal springs (P5, P6 and P34) and thirty cold water samples (with P-numbers) were monitored from 2009 to 2014 in the study area (Fig. 8). The concentrations of major ions, some heavy metals and isotopes were determined in the water samples. During field surveys, some physical parameters of the geothermal fluid, including temperature $\left({ }^{\circ} \mathrm{C}\right), \mathrm{pH}$, and electrical conductivity (EC, $\mu \mathrm{S} / \mathrm{cm}$ ), were measured in-situ with a WTW Multi 340i/SETS. The pH-meter was calibrated with $\mathrm{pH} 4, \mathrm{pH} 7$, and $\mathrm{pH} 10$ buffer solutions before commencing field work. In order to determine the variation in mineral content of the water samples, they were collected in unused 50,500 , and $1000 \mathrm{~mL}$ hard-plastic bottles. To prevent the formation of heavy metal complexes with oxygen, samples were acidified with $\mathrm{HNO}_{3}$ to $\mathrm{pH} 2$. Acidified samples were analyzed for major and trace elements with an ICP-MS (inductively coupled plasma mass spectrometer) at ACME Labs (Canada). A non-acidified sample was used for anion analyses. Chlorine and $\mathrm{HCO}_{3}{ }^{-}$were determined volumetrically and $\mathrm{SO}_{4}{ }^{2-}$ by a gravimetric method in the İzmir Institute of Technology (IIT). Also, $\mathrm{SiO}_{2}$ was determined spectrophotometrically in the IIT. Samples for determination of deuterium $\left({ }^{2} \mathrm{H}\right)$, oxygen-18 $\left({ }^{18} \mathrm{O}\right)$ and tritium $\left({ }^{3} \mathrm{H}\right)$ analyses were examined at Hacettepe University.

\subsubsection{Physical properties of water resources}

In the study area, geothermal fluids have surface discharge temperatures in the range of $32.5-33.5^{\circ} \mathrm{C}$, and cold waters have temperature values between 10.3 and $23.6^{\circ} \mathrm{C}$ (Table 1). The Gülbahçe sub-basin, which hosts a geothermal field, has the highest surface temperatures (P5 and P6) with Ilıksu hot-spring (P34) on the northern area. The area is also characterized by shallow seawater and cooler meteoric water intrusion at the intersection of the Sögütköy and İçmeler Faults and other minor parallel fractures and faults. Electrical conductivity (EC) values of geothermal fluid are nearly $37,200(\mu \mathrm{S} / \mathrm{cm})$ and cold water has values ranging from 145 to $3810(\mu \mathrm{S} / \mathrm{cm})$ (Table 1$)$.

\subsubsection{Chemical properties of water resources}

The semi-logarithmic Schoeller diagram (Fig. 9) shows that geothermal fluid samples (P5, P6 and P34) have a similar composition and it can be seen from the plots that their Sodium $\left(\mathrm{Na}^{+}\right)$ and Chloride $\left(\mathrm{Cl}^{-}\right)$concentrations are relatively higher than other chemical constituents (Table 2). The composition of geothermal fluid samples is similar to seawater, but with increased $\mathrm{Na}^{+}$and $\mathrm{K}^{+}$concentration and some depletion in $\mathrm{Mg}^{2+}$ and $\mathrm{SO}_{4}{ }^{2-}$. The $\mathrm{Na}^{+}$ is the major cation in the hot-springs of the study area with concentration ranges from 10,750 to $12,777 \mathrm{mg} / \mathrm{l}$. Also, it can be observed that magnesium $\left(\mathrm{Mg}^{2+}\right)$ and calcium $\left(\mathrm{Ca}^{2+}\right)$ have high concentrations. The chloride $\left(\mathrm{Cl}^{-}\right)$concentration in the geothermal fluids ranges from 19,632 to $23,418 \mathrm{mg} / \mathrm{l}$ and other two major anions, sulfate $\left(\mathrm{SO}_{4}{ }^{2-}\right)$ and bicarbonate $\left(\mathrm{HCO}_{3}{ }^{-}\right)$, have much lower concentrations than $\mathrm{Cl}^{-}$. In the geothermal fluid, $\mathrm{Cl}^{-}$concentration is much more than $19,000 \mathrm{mg} / \mathrm{l}$ and bromine $\left(\mathrm{Br}^{-}\right)$concentration ranges from 2.55 to $79 \mathrm{mg} / \mathrm{l}$, which is higher than that of other cold water in the study area.

The high-flowing cold water spring formed in fractured karstic limestones at İçmeler Spring (P8) has high concentrations of $\mathrm{Na}^{+}$ and $\mathrm{Cl}^{-}$, which also emerges along the NW-SE-trending Içcmeler fault. This indicates that the higher $\mathrm{Na}^{+}$and $\mathrm{Cl}^{-}$concentration values of the İçmeler Spring could be related to sea-water intrusion in karstic limestones along the İçmeler Fault. Likewise, other cold water sources located in alluvium deposits near the Gülbahçe Bay have higher concentrations of $\mathrm{Cl}^{-}$and also $\mathrm{Ca}^{2+}$ and $\mathrm{Na}^{+}$. These wells have been affected by sea-water intrusion. Bicarbonate is known as the typical main cation in most cold water samples. Considering observation of higher bicarbonate values with $\mathrm{Ca}^{2+}$ in cold water samples, it can be clarified that the reservoir for these samples are similar and water comes from the limestones and dolomites of the Nohutalan and Güvercinlik formations.

In the Piper diagram, the total cation and anion concentrations are plotted as percentages of meq/l and it's very useful to find detailed information about the concentration of the waters and hydrogeochemical facies classification. In the Piper diagram adjacent and grouped plots show that these water samples have nearly similar compositions. Following the Piper's diagram (Fig. 10), the water plots are inside the non-carbonate and high-alkalinity water area. All sample plots (except for hot water) indicate that the waters of the study area have mixed water type with no ion (cation-anion) exceeding a percentage of 50. Piper diagram also shows that hotwater springs in the study area (P5, P6, P34) can be classified as sodium-chloride enriched waters. 
Table 1

$\mathrm{EC}(\mu \mathrm{S} / \mathrm{cm})$ and $\mathrm{T}\left({ }^{\circ} \mathrm{C}\right)$ values of analyses samples from Gülbahçe region.

\begin{tabular}{|c|c|c|c|c|c|c|}
\hline Sample No & $\mathrm{X}$ & $\mathrm{Y}$ & Type & Location & $\mathrm{T}\left({ }^{\circ} \mathrm{C}\right)$ & $\mathrm{EC}(\mu \mathrm{S} / \mathrm{cm})$ \\
\hline P1 & 0468626 & 4245279 & Spring & Gülbahçe & 20 & 223 \\
\hline P2 & 0468981 & 4246823 & Well & Gülbahçe & 21 & 208,7 \\
\hline P3 & 0468220 & 4244408 & Well & Gülbahçe Drinking Water & 21 & 145,3 \\
\hline P4 & 0468986 & 4242439 & Well & Gülbahçe & 23,6 & 881 \\
\hline P5 & 0469781 & 4242636 & Geothermal fluid & Gülbahçe & 33,5 & 37200 \\
\hline P6 & 0469754 & 4242591 & Geothermal fluid & Gülbahçe & 32,5 & 37200 \\
\hline P7 & 0467899 & 4238525 & Well & Tatar Stream & 23,4 & 249 \\
\hline P8 & 0471591 & 4240446 & Spring & İçmeler & 20 & 3810 \\
\hline P9 & 0471413 & 4230018 & Spring & Yağhane & 22,5 & 493 \\
\hline P10 & 0469909 & 4241176 & Well & IYTE Benzinlik & 19,8 & 1305 \\
\hline P11 & 0477306 & 4243040 & Well & Well_80m & 18,9 & 539 \\
\hline P12 & 0477216 & 4243473 & Well & Well_140m & 20,2 & 532 \\
\hline P13 & 0475758 & 4244924 & Well & Well_186m & 22,7 & 495 \\
\hline P14 & 0475363 & 4246815 & Spring & Özbek Plain & 18,7 & 570 \\
\hline P15 & 0474474 & 4246631 & Well & Özbek Drinking Water & 20 & 384 \\
\hline P16 & 0472812 & 4250663 & Spring & Ilıksu & 20,6 & 340 \\
\hline P17 & 0473442 & 4249264 & Well & Ilıksu & 21,7 & 570 \\
\hline P18 & 0473836 & 4245876 & Well & Özbek Plain & 20,1 & 494 \\
\hline P19 & 0474594 & 4241709 & Well & Turasan Settlement & 22,2 & 1804 \\
\hline P20 & 0474890 & 4240812 & Well & Turasan Telekom & 20,5 & 1145 \\
\hline P21 & 0471339 & 4240599 & Spring & İçmeler Plain & 21,6 & 3730 \\
\hline P22 & 0471672 & 4236802 & Spring & Yağcılar Settlement & 21,1 & 579 \\
\hline P23 & 0472663 & 4231088 & Spring & Demirci Settlement & 22,3 & 847 \\
\hline P24 & 0472506 & 4239505 & Well & İçmeler Settlement & 20,2 & 560 \\
\hline P25 & 0473406 & 4239615 & Dug well & İçmeler Plain & 20,5 & 724 \\
\hline P26 & 0473978 & 4240893 & Dug well & İçmeler Plain & 19,6 & 1326 \\
\hline P27 & 0473150 & 4240475 & Dug well & İçmeler Plain & 19,4 & 1676 \\
\hline P28 & 0467677 & 4240521 & Dug well & İçmeler Plain & 21,7 & 187,4 \\
\hline P29(30) & 0468177 & 4242189 & Well & IYTE Dormitory & 19,3 & 200,5 \\
\hline P31 & 0468388 & 4244270 & Well & Gülbahçe Drinking Water & 10.3 & 2081 \\
\hline P32 & 0468125 & 4241996 & Well & IYTE Dormitory & 11.5 & 231 \\
\hline P33 & 0464201 & 4240051 & Well & Tepe kahve & 13.7 & 152 \\
\hline P34 & 0472588 & 4251467 & Geothermal fluid & Ilıksu & 33 & 30800 \\
\hline
\end{tabular}

* Samples locations have same coordinates $(\mathrm{X}, \mathrm{Y})$.

Table 2

Concentration of major anion and cation in water resource.

\begin{tabular}{|c|c|c|c|c|c|c|c|c|c|c|}
\hline Sample No & $\mathrm{Ca}^{2+}$ & $\mathrm{Mg}^{2+}$ & $\mathrm{Na}^{+}$ & $\mathrm{K}^{+}$ & $\mathrm{Cl}^{-}$ & $\mathrm{SO}_{4}{ }^{2-}$ & $\mathrm{HCO}_{3}{ }^{-}$ & $\mathrm{Br}^{-}$ & $\mathrm{B}^{3+}$ & $\mathrm{Li}^{+}$ \\
\hline P4 & 139.60 & 31.08 & 150.85 & 18.43 & 337.30 & 56.19 & 311.10 & 1.12 & 0.07 & 0.01 \\
\hline P5 & 1307.80 & 1172 & 12777 & 490 & $23,418.00$ & $2,960.60$ & 130.54 & 78.91 & 5.38 & 1.00 \\
\hline P6 & 1273.30 & 1136 & 12589 & 464 & $22,864.00$ & $3,014.50$ & 107.36 & 75.68 & 5.24 & 1.00 \\
\hline P7 & 21.58 & 8.44 & 49.65 & 5.02 & 33.61 & 11.17 & 126.88 & 0.11 & 0.11 & 0.04 \\
\hline P08 & 208.20 & 109.00 & 982 & 40.00 & $1,618.30$ & 233.71 & 283.04 & 5.34 & 0.40 & 1.00 \\
\hline P10 & 125.82 & 23.55 & 116.33 & 4.15 & 284.11 & 95.39 & 202.52 & 0.87 & 0.04 & 0.01 \\
\hline P11 & 107.97 & 19.42 & 28.23 & 25.04 & 35.33 & 48.01 & 331.84 & 0.13 & 0.10 & 0.02 \\
\hline P12 & 102.60 & 15.33 & 46.21 & 3.55 & 65.81 & 78.43 & 209.84 & 0.20 & 0.05 & 0.04 \\
\hline P14 & 150.42 & 12.32 & 23.72 & 5.04 & 35.47 & 42.66 & 372.10 & 0.17 & 0.06 & 0.01 \\
\hline P15 & 105.59 & 5.64 & 17.46 & 1.93 & 30.06 & 10.73 & 261.08 & nd & 0.03 & 0.01 \\
\hline P16 & 80.49 & 4.06 & 20.11 & 0.38 & 43.66 & 11.68 & 186.66 & 0.14 & 0.03 & 0.01 \\
\hline P20 & 180.72 & 17.73 & 153.05 & 4.76 & 405.39 & 52.29 & 275.72 & 1.28 & 0.08 & 0.01 \\
\hline P22 & 146.84 & 4.28 & 22.41 & 5.25 & 53.54 & 23.76 & 329.40 & 0.20 & 0.03 & 0.01 \\
\hline P23 & 138.78 & 32.62 & 64.35 & 13.57 & 150.33 & 63.03 & 364.78 & 0.15 & 0.09 & 0.04 \\
\hline P24 & 106.12 & 27.16 & 27.34 & 1.15 & 58.72 & 24.78 & 339.16 & 0.22 & 0.02 & 0.01 \\
\hline P29 & 20.80 & 7.56 & 28.38 & 5.60 & 32.26 & 7.79 & 52.46 & 0.12 & 0.04 & 0.02 \\
\hline P31 & 25.16 & 7.62 & 22.47 & 5.43 & 28.92 & 15.20 & 107.36 & nd & 0.04 & 0.01 \\
\hline P32 & 20.26 & 6.96 & 27.36 & 5.67 & 32.08 & 8.14 & 97.60 & 0.10 & 0.05 & 0.02 \\
\hline P33 & 14.56 & 3.84 & 18.85 & 5.93 & 24.93 & 4.32 & 58.56 & 0.11 & 0.03 & 0.01 \\
\hline P34 & 886.30 & 1144 & 10750 & 413 & $19,632.00$ & $2,418.60$ & 153.72 & 2.55 & 4.81 & 1.00 \\
\hline SW & 5014.00 & 1361.04 & $12,229.89$ & 430 & $22,722.44$ & $3,266.09$ & 192.194 & & & \\
\hline
\end{tabular}

* Seawater data from Tarcan (2002).

All samples are classified according to $\mathrm{Cl}-\mathrm{SO}_{4}-\mathrm{HCO}_{3}$ diagram (from Giggenbach, 1988) and shown in Fig. 11. Geothermal samples are located close to the seawater point. The other cold spring and cold groundwater resources are classified as peripheral water. Some springs (P4, P08) and groundwater samples (P10, P20) are affected by seawater intrusion. These waters have high $\mathrm{Cl}^{-}$concentration.

\subsubsection{Isotopic composition of water resources}

Stable isotopes are a very useful analysis method for determining origin and transit time and direction of fluids of the groundwater system. The water samples were analyzed to determine isotopic ratios of deuterium $\left({ }^{2} \mathrm{H}\right)$, oxygen-18 $\left({ }^{18} \mathrm{O}\right)$ and tritium $\left({ }^{3} \mathrm{H}\right)$ (Table 3). Fig. 12 indicates the relationship of $\delta^{18} \mathrm{O}$ and $\delta^{2} \mathrm{H}$; deuterium $\left(\delta^{2} \mathrm{H}\right)$ values are in the range from -32.50 to $2.55 \%$ and oxygen-18 $\left(\delta^{18} \mathrm{O}\right)$ values are in the range from -6.06 to $0.67 \%$. The graph results also show that the cold water samples appear 


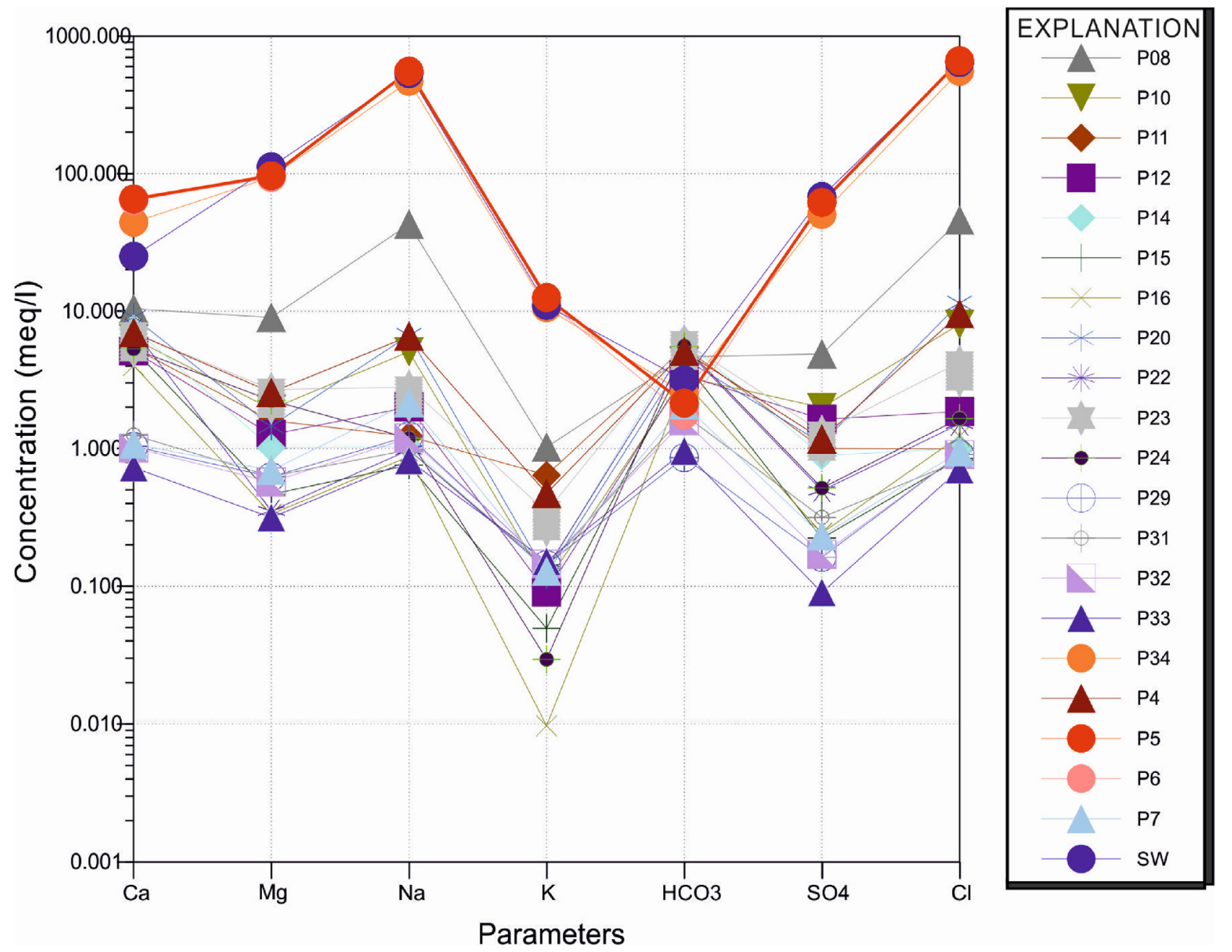

Fig. 9. Schoeller semi-logarithmic diagram for waters in the Gülbahçe region.

Table 3

Isotopic composition of water resources around Gülbahçe geothermal field.

\begin{tabular}{|c|c|c|c|c|c|}
\hline Sample No & $\begin{array}{l}\delta^{2} \mathrm{H} \text { Value } \\
\text { (permil) }\end{array}$ & $\begin{array}{l}\delta^{2} \mathrm{H} \text { Standard } \\
\text { Deviation } \\
\text { (permil) }\end{array}$ & $\begin{array}{l}\delta^{18} \text { O Reportable } \\
\text { Value (permil) }\end{array}$ & $\begin{array}{l}\delta^{18} \text { O Standard } \\
\text { Deviation } \\
\text { (permil) }\end{array}$ & $\begin{array}{l}\delta^{3} \mathrm{H} \text { Value } \\
\text { (TU) }\end{array}$ \\
\hline P4 & -26.81 & 0.82 & -4.63 & 0.09 & 0.23 \\
\hline P5 & 2.55 & 0.49 & 0.67 & 0.21 & 0 \\
\hline P6 & 0.82 & 0.69 & 0.54 & 0.03 & 0 \\
\hline P7 & -30.42 & 0.00 & -5.64 & 0.08 & 0.78 \\
\hline P8 & -29.53 & 0.88 & -5.42 & 0.08 & 2.39 \\
\hline P10 & -27.47 & 0.62 & -5.23 & 0.05 & 3.35 \\
\hline P11 & -28.62 & 0.29 & -5.10 & 0.08 & 1.51 \\
\hline P12 & -29.42 & 0.36 & -5.22 & 0.10 & 0.85 \\
\hline P14 & -27.85 & 0.21 & -4.96 & 0.08 & 3.55 \\
\hline P15 & -31.19 & 0.52 & -5.57 & 0.15 & 1.74 \\
\hline P16 & -30.81 & 0.75 & -5.64 & 0.09 & 4.55 \\
\hline P20 & -27.78 & 0.28 & -4.89 & 0.07 & - \\
\hline P22 & -31.33 & 0.14 & -5.48 & 0.19 & 3.54 \\
\hline P23 & -31.11 & 0.36 & -5.21 & 0.04 & 1,70 \\
\hline P24 & -29.55 & 0.49 & -5.68 & 0.07 & 4.55 \\
\hline P29 & -31.11 & 0.17 & -5.82 & 0.15 & - \\
\hline P31 & -32.49 & 0.81 & -6.06 & 0.07 & - \\
\hline P32 & -32.46 & 0.52 & -5.76 & 0.09 & - \\
\hline P33 & -32.50 & 0.36 & -5.75 & 0.10 & - \\
\hline P34 & -1.89 & 0.70 & -0.45 & 0.09 & 0 \\
\hline SW & 10.10 & & 0.96 & & 10 \\
\hline
\end{tabular}

* Seawater data from Filiz (1982).

to have meteoric origin, while the hot water samples are classified as oxygen-enriched waters (Fig. 12). Oxygen enrichment indicator shows that the reservoir rock temperature may be high. Tritium $\left({ }^{3} \mathrm{H}\right)$ isotope analysis $(\mathrm{TU}<5)$ showed that geothermal fluids are 


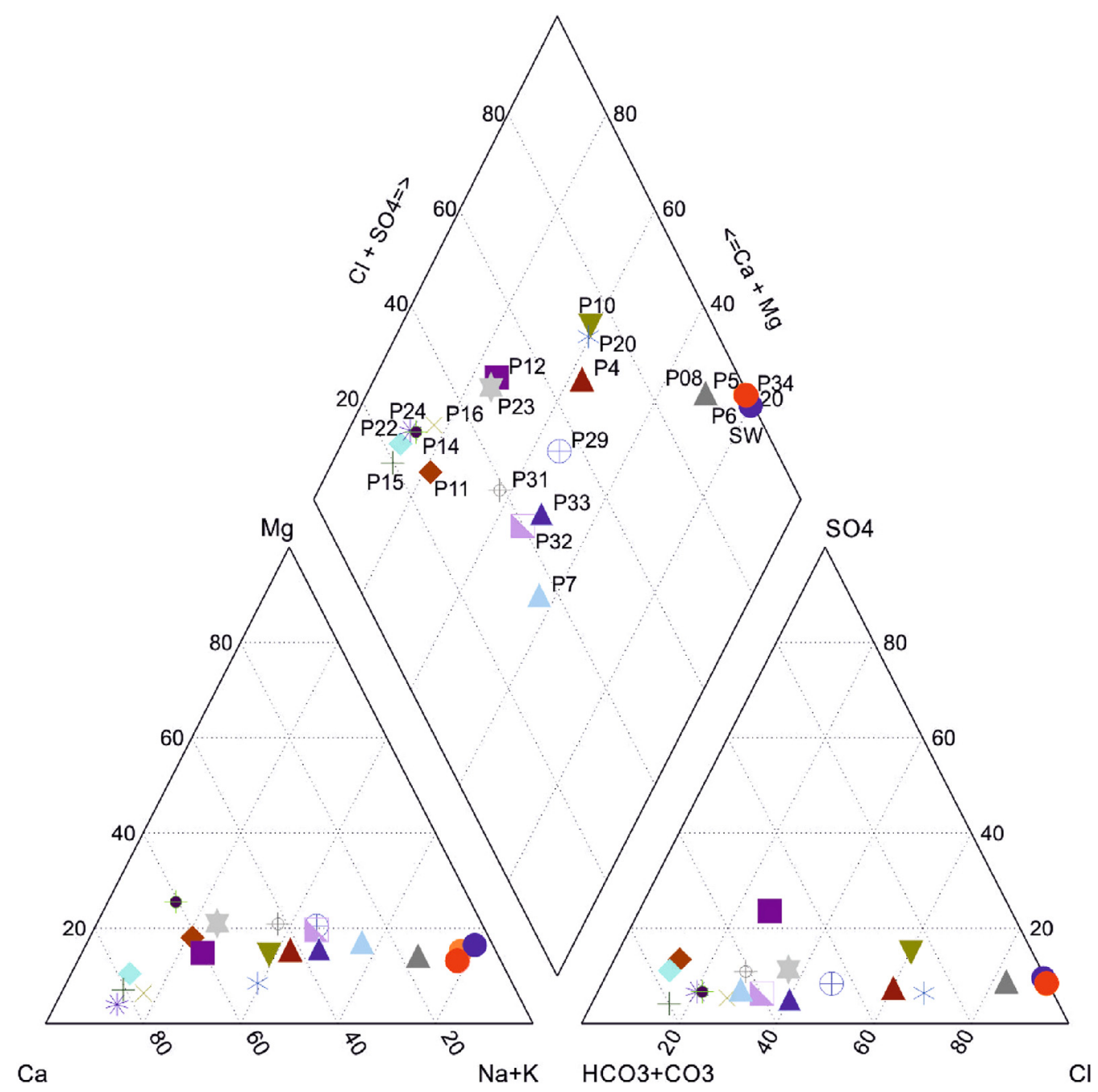

Fig. 10. Piper-trilinear diagram of water samples from Gülbahçe region.

older than 60 years. Also, the relationship diagram of deuterium $\left({ }^{2} \mathrm{H}\right)$ and tritium $\left({ }^{3} \mathrm{H}\right)$ shows that geothermal fluid has deep water circulation (Fig. 13). Isotopic results $\left(\delta^{2} \mathrm{H}, \delta^{13} \mathrm{H}, \delta^{18} \mathrm{O}\right)$ show that geothermal samples are rather similar to seawater. Isotopic compositions of geothermal samples are almost unaltered seawater but geothermal fluid ions such as $\mathrm{Ca}^{2+}, \mathrm{Mg}^{2+}$ and $\mathrm{HCO}_{3}{ }^{-}$do not have a close similarity to seawater. Similar results have been observed in some geothermal systems such as Baja California Peninsula in Mexico (Barragán et al., 2001).

\subsubsection{Chemical geothermometers applications}

The reservoir temperature of geothermal systems can be predicted by cation geothermometers. Empirical geothermometer equations were developed by White $(1957,1970)$, Ellis and Mahon (1967), Ellis (1970), Truesdell (1976), Fournier (1979, 1992), Arnórsson et al. (1983), Nieva and Nieva, (1987), Giggenbach (1988, 1992) and Nicholson (1993). Geothermometers can provide temperature values if waters mix after equilibrium was attained. The cationic composition geothermometers (Nieva and Nivea, 1987) have shown estimated temperatures close to measured temperatures in a number of cases, especially for deep fluids, diluted during ascent with shallow cold water. Temperatures of thermal fluid were calculated by the following geothermometers: cation geothermometers Na/K (Truesdell, 1976; Tonani, 1980; Arnórsson et al., 1983; Nieva and Nieva, 1987; Giggenbach, 1988), K/Mg
(Giggenbach et al., 1983), Na-K-Mg (Giggenbach, 1988) and silica (Fournier, 1979; Fournier and Potter, 1982; Arnórsson et al., 1983).

\subsection{The $\mathrm{Na} / \mathrm{K}$ geothermometer}

The $\mathrm{Na} / \mathrm{K}$ Geothermometer is based on the exchange of $\mathrm{K}^{+}$ and $\mathrm{Na}^{+}$ions in reservoir conditions. The $\mathrm{Na} / \mathrm{K}$ geothermometer uses theoretical regulations controlled by thermodynamic and chemical conditions to find possible maximum temperatures in deep geothermal systems. It provides additional data about deeper conditions and thermal characteristics of geothermal fluid. Many $\mathrm{Na} / \mathrm{K}$ geothermometer functions have been presented by different authors so far. The chemical results show that a reservoir temperature for geothermal fluid in the Gülbahçe region ranges from 103 to $167^{\circ} \mathrm{C}$ (Table 4 ).

\section{4. $\mathrm{K} / \mathrm{Mg}$ geothermometer}

$\mathrm{K} / \mathrm{Mg}$ geothermometer was first proposed by Giggenbach et al. (1983) and then Giggenbach (1988) developed an equation for this geothermometer. The $\mathrm{K} / \mathrm{Mg}$ geothermometer is useful for temperature ranges of $50-300^{\circ} \mathrm{C}$ and is especially used for low to moderate temperature systems (Nicholson, 1993). Different from $\mathrm{Na} / \mathrm{K}$ geothermometers, the $\mathrm{K} / \mathrm{Mg}$ geothermometers are quickly affected by temperature changes and reflect the most recent temperature values of geothermal fluid. The $\mathrm{K} / \mathrm{Mg}$ geothermometer is 


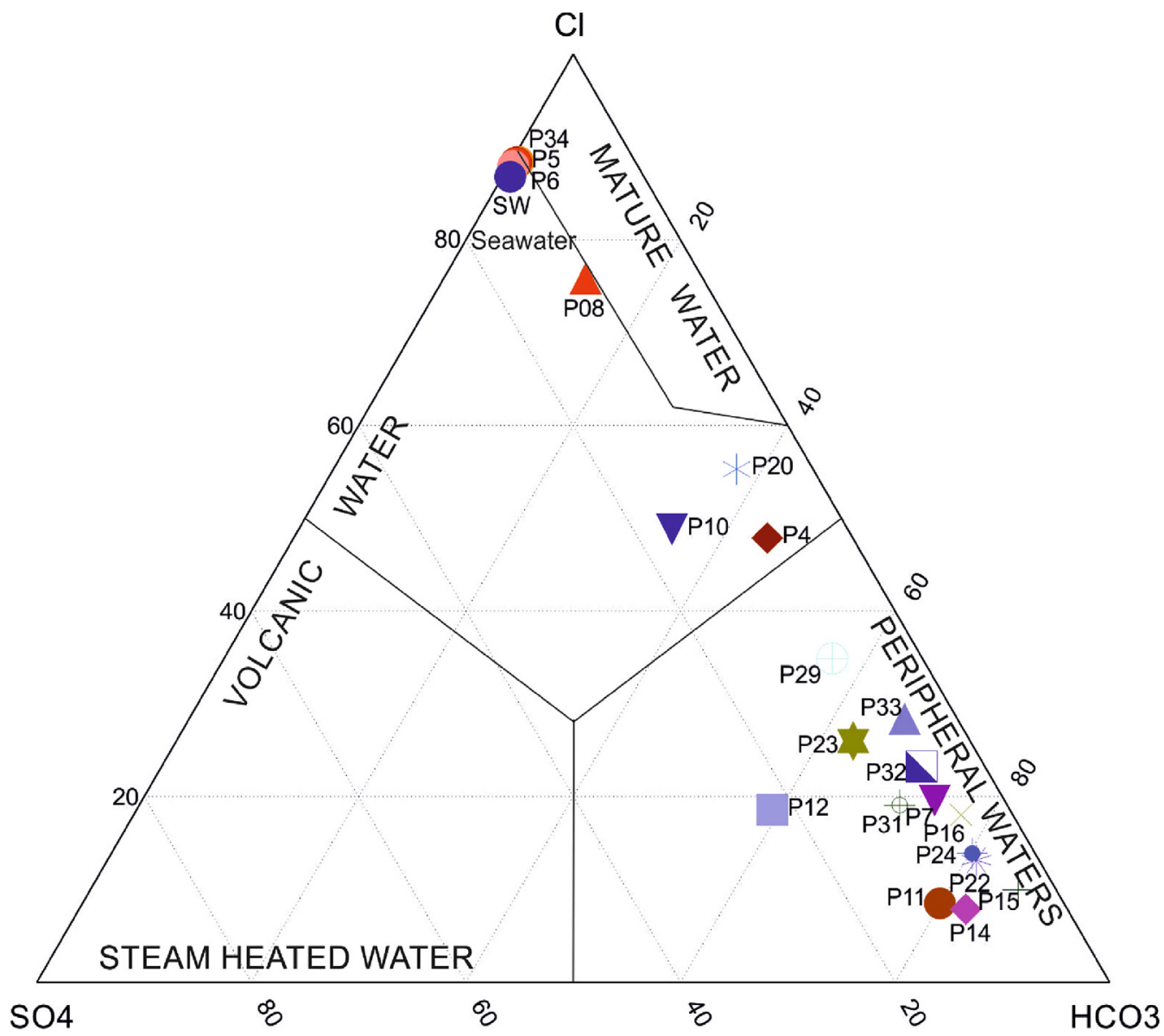

Fig. 11. $\mathrm{Cl}-\mathrm{SO}_{4}-\mathrm{HCO}_{3}$ ternary diagram for the samples (Giggenbach, 1988).

Table 4

$\mathrm{The} \mathrm{Na} / \mathrm{K}, \mathrm{K} / \mathrm{Mg}$ and Silica geothermometer equations with estimated temperatures of samples in this study.

\begin{tabular}{|c|c|c|c|c|c|}
\hline \multirow[t]{2}{*}{ Type } & \multirow[t]{2}{*}{ Authors } & \multirow[t]{2}{*}{ Equations } & \multicolumn{3}{|c|}{ ESTIMATED TEMPERATURES OF SAMPLES } \\
\hline & & & NO: P5 & NO: P6 & NO: P34 \\
\hline \multirow[t]{4}{*}{$\mathrm{Na} / \mathrm{K}$} & Truesdell (1976) & $\mathrm{t}^{\circ} \mathrm{C}=856 /[\log (\mathrm{Na} / \mathrm{K})+0.857]-273$ & 103 & 104 & 104 \\
\hline & Tonani (1980) & $t^{\circ} \mathrm{C}=883 /[\log (\mathrm{Na} / \mathrm{K})+0.780]-273$ & 106 & 107 & 106 \\
\hline & Arnórsson et al. (1983) & $t^{\circ} \mathrm{C}=933 /[\log (\mathrm{Na} / \mathrm{K})+0.993]-273$ & 114 & 115 & 114 \\
\hline & Nieva and Nieva (1987) & $\mathrm{t}^{\circ} \mathrm{C}=1178 /[\log (\mathrm{Na} / \mathrm{K})+1.470]-273$ & 135 & 136 & 135 \\
\hline K-Mg & Giggenbach (1988) & $\mathrm{t}^{\circ} \mathrm{C}=4410 /[\log (\mathrm{K} / \mathrm{Mg}) 1 / 2+14.0]-273$ & 110 & 109 & 115 \\
\hline \multirow{3}{*}{ Silica } & Fournier (1979) & $\mathrm{t}^{\circ} \mathrm{C}=1522 /[(5.75-\log (\mathrm{S}))]-273$ & 60 & 62 & 57 \\
\hline & Fournier and Potter (1982) & $t^{\circ} \mathrm{C}=-42.2+0.28832 S-3.6686 \times 10^{-4} S^{2}+3.1665 \times 10^{-7} S^{3}+77.034 \log S$ & 53 & 55 & 50 \\
\hline & Arnórsson et al. (1983) & $\mathrm{t}^{\circ} \mathrm{C}=1498 /[(5.7-\log (\mathrm{S}))]-273$ & 60 & 60 & 59 \\
\hline
\end{tabular}

based on rapid $\mathrm{Mg}$ cation exchange reactions at lower temperatures, and provides representative data for fluid-rock interactions and temperature ranges of fluids just before leaving the geothermal reservoir (Nicholson, 1993). The K/Mg chemical geothermometer results calculated for water samples from the GGF are presented in Table 4. According to the results, it can be estimated that the temperature of the geothermal reservoir ranges from 109 to $115^{\circ} \mathrm{C}$.

\subsection{Silica geothermometer}

Silica geothermometers are based on experimentally determined variations in the solubility of different silica species (i.e., quartz, amorphous silica, and chalcedony) in a reservoir, as a function of temperature and pressure. The silica geothermometer results calculated for geothermal fluid of GGF are presented in Table 4. The concentration of $\mathrm{SiO}_{2}$ in the geothermal fluid ranges from 14 to $16 \mathrm{mg} / \mathrm{l}$ in geothermal fluid. According to the results it can be estimated that the temperature of the geothermal reservoir ranges from 53 to $62^{\circ} \mathrm{C}$. Silica reservoir temperatures are lower than the cation geothermometer temperatures. This result shows that loss of silica is associated with dilution by waters with comparatively lower silica content.

\subsection{Na-K-Mg geothermometer}

The Na-K-Mg diagram (Fig. 14) proposed by Giggenbach (1988) is often used to visualize equilibrium between reservoir rocks and waters with aquifer temperatures. Fig. 13 shows that cold-water samples fall in the immature water region close to the $\mathrm{Mg}$ corner and geothermal fluid samples fall in the partial equilibrium region and therefore, $\mathrm{Na} / \mathrm{K}, \mathrm{K}-\mathrm{Mg}$ and other cation geothermometers can be applied to hot water samples. 


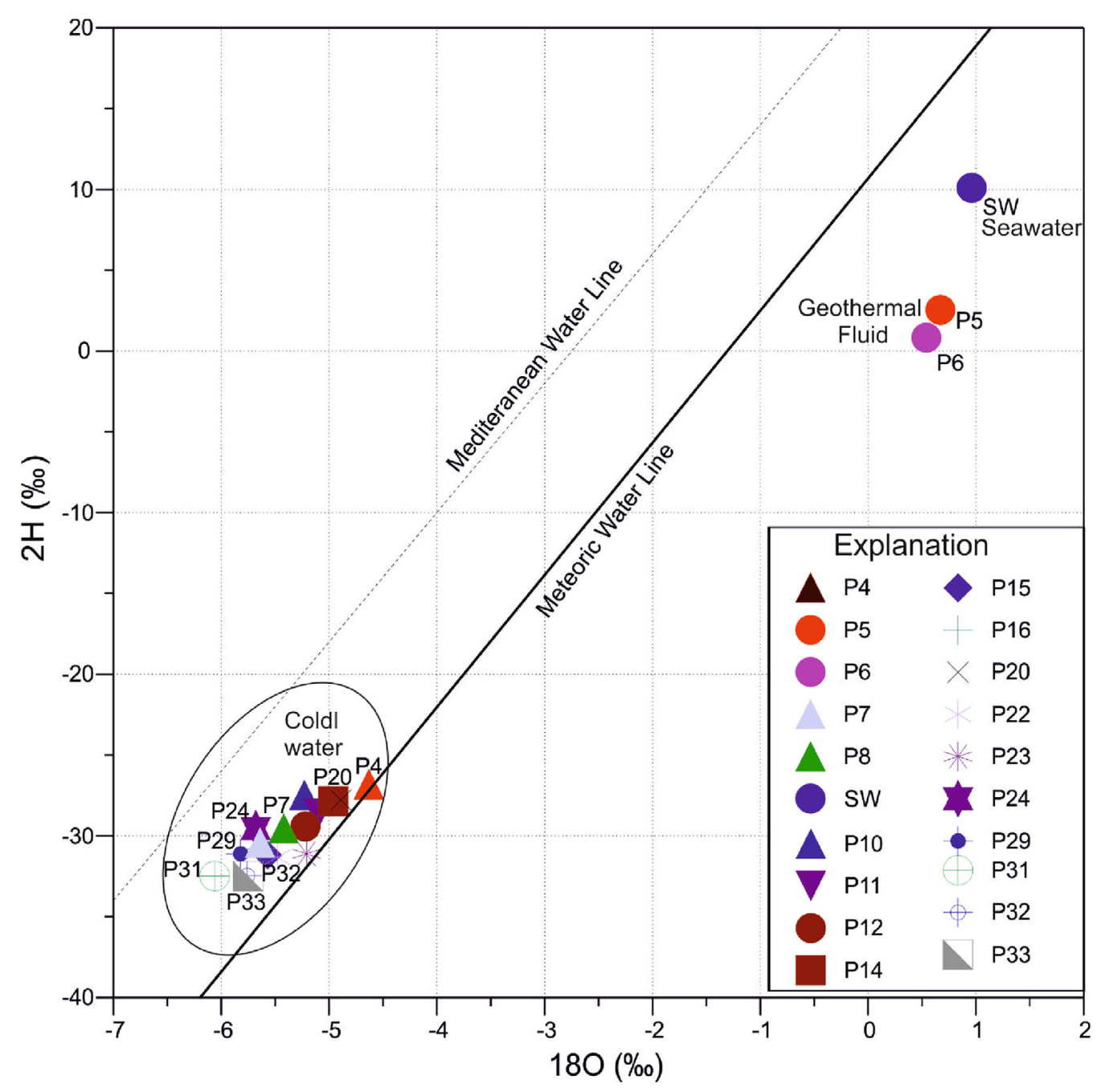

Fig. 12. The relation diagram of deuterium $\left({ }^{2} \mathrm{H}\right)$ versus oxygen- $18\left({ }^{18} \mathrm{O}\right)$ for the water samples in the Gülbahçe geothermal field.

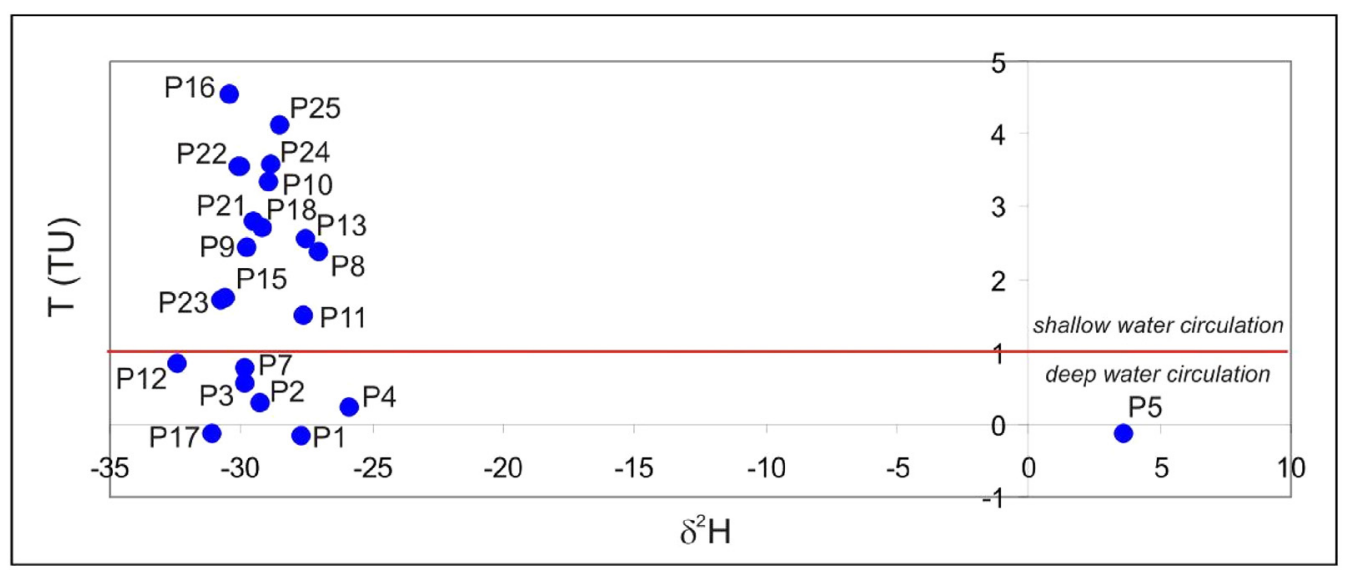

Fig. 13. The relation diagram of deuterium $\left({ }^{2} \mathrm{H}\right)$ and tritium $\left({ }^{3} \mathrm{H}\right)$ for the water samples in the Gülbahçe geothermal field.

Partial equilibration is a result of high magnesium concentration in water samples due to mixing of cold water from limestone and dolomite units. The sample plots in the area of immature waters reflects that attainment of equilibrium between water and rock does not exist because of possible fast circulation of waters in fractured aquifers of Gülbahçe geothermal system. Gulbahce
Geothermal fluid samples are relatively close to the seawater point which suggests a close interrelationship.

\section{Discussion and conclusions}

According to previous studies (Faulds et al., 2004; Faulds et al., 2010; Faulds and Hinz, 2015), most of the well-known geothermal 


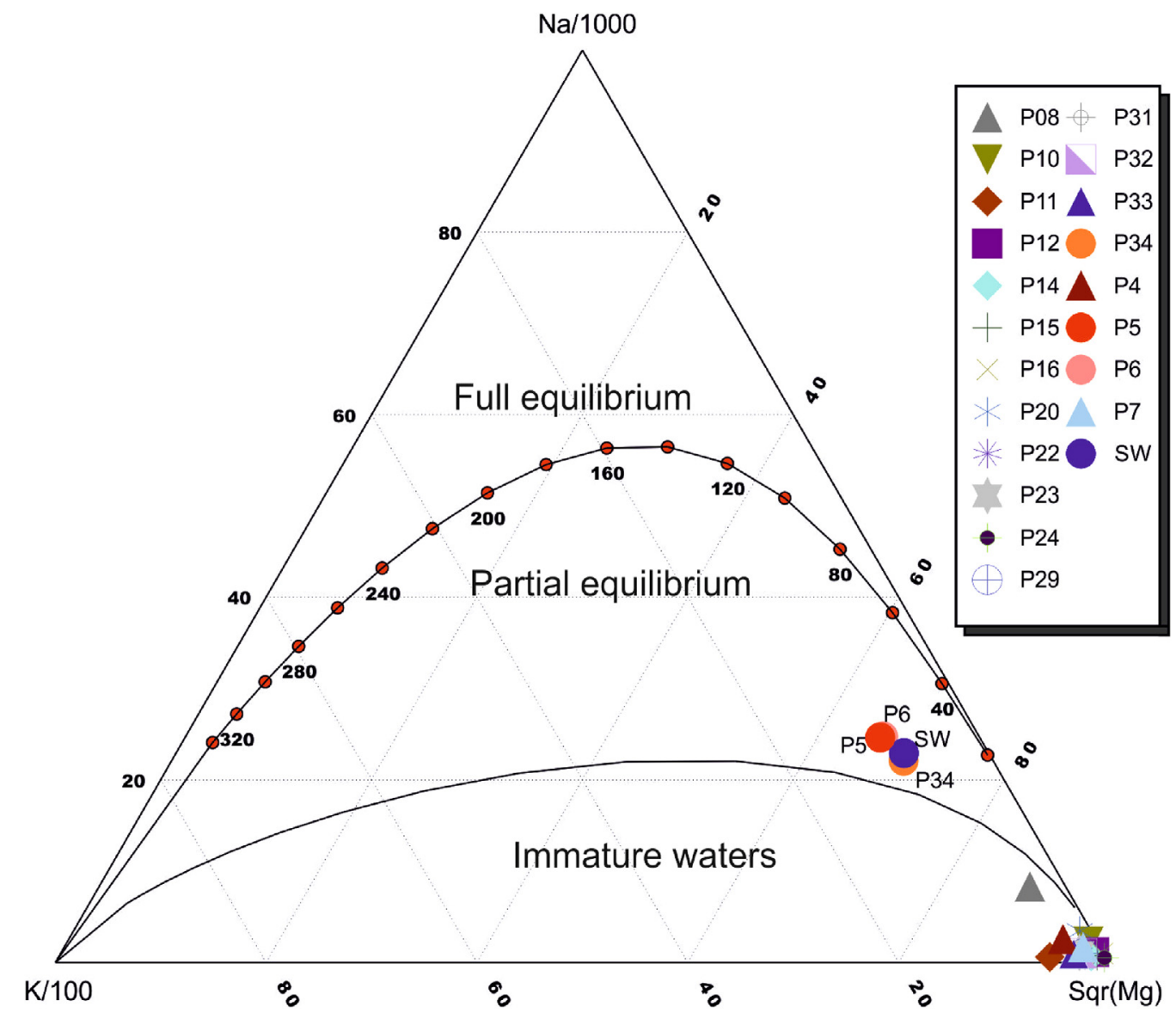

Fig. 14. Distribution of water samples from study area in Na-K-Mg triangular diagram (Giggenbach 1988).

areas such as the Great Basin (USA) and Büyük Menderes Graben (Turkey) are related to crustal extension and active normal faulting. These faults allow the circulation of hydrothermal fluids in deep reservoirs and generally are primary controlling structures in geothermal areas. The most suitable geological structures for geothermal activity in extensional tectonic settings are generally; major normal fault planes, bending fault segments, relay ramps and accommodation zones between normal faults. However, strike-slip tectonics is the product of dominantly transtensive, transpressive and pure strike-slip stress regimes and systems could reach deeper levels with steeply dipping fault planes. For a region-dominated by strike-slip faulting, pull-apart basins, displacement transfer zones, fault bends, step-overs and horse-tail fault terminations are the most important tectonic structures for geothermal activity (Faulds et al., 2010; Faulds and Hinz, 2015).

Studies of the structural geology and fault kinematics in the Gülbahçe area suggest the evolution of the geothermal system is affected by a transtensional tectonic regime. Tectonic structures and deformation must vary on a $6 \mathrm{~km}$ long fault zone but in Gülbahçe sub-basin, the transtensional regime manifests itself as a transtensional pull-apart like opening basin structure. The structural map of the field shows a pattern with dominantly $\mathrm{N}$ S-trending fault planes. Active extension across the normal faults maintains flow paths for geothermal fluids and shapes the networks of interconnected shear and tensile brittle fractures. For example, NE-SW directed Söğütköy fault and NW-SE directed İçmeler fault play important role in the geothermal system with its trend compatible with the GFZ.

Based on hydrogeochemical data, deep flows occur in basement units and ascending hot-fluids are trapped and confined by semi/non-permeable Miocene units. However, geothermal fluids moved up along GFZ fault segments, which are responsible for secondary permeability and porosity. The zone shown as an 'accommodation zone' in Fig. 15 represents the area affected by intersecting faults and very suitable for uprising and deposition of geothermal fluids. As mentioned before pull-apart basins in transtensional strike-slip environments are an important focus for geothermal manifestations. The Gülbahçe sub-basin with explained accommodation zone, includes convenient geothermal features such as a high permeable fracture zone, intersections of faults and joints, and a nearby relay ramp. Also, like most fracturecontrolled systems, permeability of Gülbahçe geothermal system is controlled by an interconnected fault-joint network of basement limestones with cooling joints, microfractures and voids of volcanic units. In addition to this brittle deformation in volcanics, the tectonic contact between Kocadağ volcanics and underlying Quaternary deposits developed as channels for fluid entries and feeds into the geothermal system.

The conceptual model indicates that the geothermal system is controlled by faults of the GFZ. The N-S directed major fault segments intersect with other faults in an accommodation zone near the study area (Fig. 15(a)) and when considering the larger scale evolution, they tectonically form a possible negative flower structure (Fig. 15(b)). This negative flower structure is consistent with the morphology of Gülbahçe bay and trend of known major fault segments. In Gülbahçe sub-basin, the N-S directed normal fault planes and NE-SW directed strike-slip (possible riedel shear features of the GFZ) faults reflect transtensional basin deformation in the main fault zone. Normal stress exists on normal fault planes such as Sögütköy and İçmeler faults, causing joints and fractures 

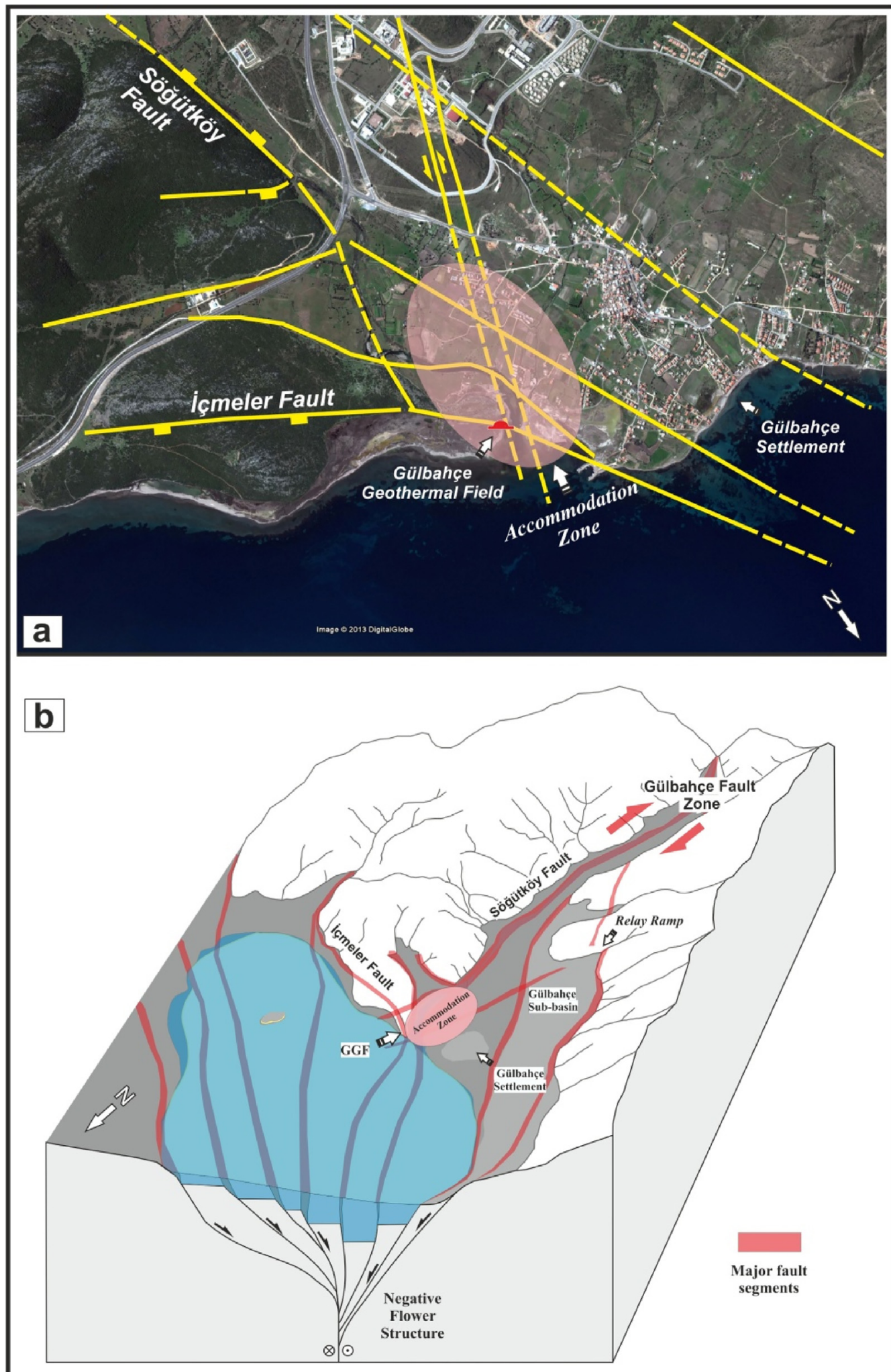

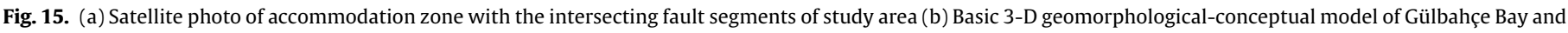
sub-basin with possible negative flower structure (unscaled).

to remain open around the GGF. However, Miocene and Quaternary cover units have E-W- and NE-SW-trending small-scale faults which do not cut and breach the cover intensely. Furthermore, compression components of the strike-slip regime on NE-SW-trending faults results in compaction, as well as filling of open fractures with clayey fault breccias so permeability may be reduced in the cap rock of the system.

Many earthquakes occur at the intersecting segments of the fault zones around Gülbahçe and Sığacık Bays and so the strikeslip dominated Gülbahçe Fault Zone is currently deforming under 
present-day stress conditions. With other major fault zones (the DYFZ, the KUFZ and the SFZ), the GFZ is affected by a strike-slip dominated shear zone the İzmir-Balıkesir Transfer Zone between Cycladic and Menderes core complexes (Uzel and Sözbilir, 2008). An intersecting fault pattern and transtensional basin structure in the Gülbahçe sub-basin is compatible with an extension-dominated transtensional phase of a transfer zone, occurring between Late Miocene and Early Pliocene. Knowledge about fault segments and strike-slip transfer zones would be very useful for identifying geothermal systems like Gülbahçe, around İzmir and Balıkesir cities.

\section{References}

Arnórsson, S., Gunnlaugsson, E., Svavarsson, H., 1983. The chemistry of geothermal waters in Iceland. III. Chemical geothermometry in geothermal investigations. Geochim. Cosmochim. Acta 47 (3), 567-577.

Baba, A., Ármannsson, H., 2006. Environmental impact of the utilization of a geothermal area in Turkey. Energy Sources 1, 267-278.

Baba, A., Sözbilir, H., 2012. Source of arsenic based on geological and hydrogeochemical properties of geothermal systems in western Turkey. Chem. Geol. 334, 364-377.

Barragán, R.M., Birkle, P., Portugal, E., Arellano, V.M., Álvarez, J., 2001. Geochemical survey of medium temperature geothermal resources from the Baja California Peninsula and Sonora, México. J. Volcanol. Geotherm. Res. 110, 101-119.

Borsi, S., Ferrara, G., Innocenti, F., Mazzuoli, R., 1972. Geochronology and petrology of recent volcanics in the Eastern Aegean Sea. Bull. Volcanol. 36, 473-496.

Bozkurt, E., Mitwede, S.K., 2001. Introduction to the geology of Turkey-a synthesis. Int. Geol. Rev. 43, 578-594.

Bozkurt, E., 2001. Neotectonics of Turkey -a synthesis. Geodinamica Acta 14, 3-30. Brinkmann, R., Flügel, E., Jacobshagen, 1972. Trias, Jura und Unterkreide der Halbinsel Karaburun (West-Anatolien). Geologie et Paleontologie 6, 139-150.

Brinkmann, R., 1966. Geotektonische Gliederung von Westanatolien. Neues Jahrbuch für Geologie und Paleontologie-Monatsheft e 10, 603-618.

Çakmakoğlu, A., Bilgin, Z.R., 2006. Pre-neogene stratigraphy of the Karaburun Peninsula (W of İzmir Turkey). Bull. Miner. Res. Explor. Inst. (MTA) Turkey 132, 33-62.

Çetiner, L., Pekatan, R., Taşkıran, A., İldem, F., 2000. İzmir-Güzelbahçe ve Gülbahçe jeotermal enerji arama projesi final raporu [İzmir-Güzelbahçe and Gülbahçe geothermal energy exploration project final report] (Report No. 10739). Mineral Research and Exploration of Turkey (MTA), Ankara.

Ellis, A.J., Mahon, W.A.J., 1967. Natural hydrothermal systems and experimental hot water/rock interaction (Part 2). Geochim. Cosmochim. Acta 31 (4), 519-539.

Ellis, A.J., 1970. Quantitative interpretation of chemical characteristics of geothermal systems. Geothermics 2, 516-528.

Erdoğan, B., Altıner, D., Güngör, T., Özer, S., 1990. The stratigraphy of karaburun peninsula. Bull. Miner. Res. Explor. Inst. (MTA) Turkey 111, 1-23.

Erdoğan, B., 1990. Tectonic relations between İzmir-Ankara zone and Karaburun belt. Bull. Miner. Res. Explor. Inst. (MTA) Turkey 110, 1-15.

Faulds, N.H., Hinz, N.H., 2015. Favorable tectonic and structural settings of geothermal settings in the Great Basin Region, Western USA: Proxies for discovering blind geothermal systems. In: Proceedings, World Geothermal Congress 2015, Melbourne, Australia.

Faulds, J.E., Coolbaugh, M., Blewitt, G., Henry, C.D., 2004. Why is Nevada in hot water? Structural controls and tectonic model of geothermal systems in the northwestern Great Basin. Geotherm. Resour. Council Trans., 649-654.

Faulds, J.E., Coolbaugh, M., Bouchot, V., Moeck, I., Oğuz, K., 2010. Characterizing structural controls of geothermal reservoirs in the Basin and Range, USA, and western Turkey: developing successful exploration strategies in extended terranes. In: Proceedings of the World Geothermal Congress, Bali, Indonesia, 25-29 April 2010

Filiz, S., Tarcan, G., 1990. Gülbahçe Körfezi güneyindeki jeotermal alanın hidrojeolojik, hidrojeokimyasal ve izotopsal incelenmesi [Hydrogeological, hydrogeochemical and isotopical investigations of geothermal area of the southern Gülbahce Bay]. Turk. Assoc. Petrol. Geol. Bull. 2/1, 69-52.

Filiz, S., 1982. Investigation of Isotopes $\left({ }^{18} \mathrm{O},{ }^{2} \mathrm{H},{ }^{3} \mathrm{H}{ }^{13} \mathrm{C}\right)$ in Important Geothermal Area in Aegean Region, Diploma of Assoc.Prof. Ege University, Izmir.

Fournier, R.O., Potter II, R.W., 1982. A revised and expanded silica (quartz) geothermometer. Geotherm. Resour. Council Bull. November, 3-12.

Fournier, R.O., 1979. A revised equation for the Na/K geothermometer. Geotherm. Resour. Council Trans. 3, 221-224.

Fournier, R. O. (1992) Water geothermometers applied to geothermal energy. In: F. D'Amore (Coordinator), Application of geochemistry in geothermal reservoir development, UNITAR/UNDP, pp. 37-69.

Giggenbach, W.F., Gonfiantini, R., Jangi, B.L., Truesdell, A.H., 1983. Isotopic and chemical composition of Parbati valley geothermal discharges NW-Himalaya, India. Geothermics 12, 199-222.

Giggenbach, W.F., 1988. Geothermal solute equilibria. Derivation of Na-K-Mg-Ca geoindicators. Geochim. Cosmochim. Acta 52, 2749-2765.

Giggenbach, W.F. (1992) Chemical techniques in geothermal exploration. In: F. D'Amore (Coordinator), Application of Geochemistry in Geothermal Reservoir Development, UNITAR/UNDP, pp. 119-144.
Helvacı, C., Ersoy, Y., Sözbilir, H., Erkül, F., Sümer, Ö., Uzel, B., 2009. Geochemistry and ${ }^{40} \mathrm{Ar} /{ }^{39} \mathrm{Ar}$ geochronology of Miocene volcanic rocks from the Karaburun Peninsula: implications for amphibole-bearing lithospheric mantle source, Western Anatolia. J. Volcanol. Geotherm. Res. 185, 181-202.

Kaya, O., 1981. Miocene reference section for the coastal parts of West Anatolia. Newslett. Stratigraphy 10, 164-191.

Kozur, H., 1997. First discovery of Muellerisphaerida (inc. sedis) and Eoalbaillella (Radiolaria) in Turkey and the age of the siliciclastic sequence (clastic series) in Karaburun peninsula. Freiberger Forschungsheft 46, 33-59.

Lechner, H., Rendel, B., Trick, P., 1967. Geologische karte von Mittel-Karaburun, Marburg.

Mutlu, H., Güleç, N., 1998. Geochemical characteristics of thermal waters from Anatolia (Turkey). J. Volcanol. Geotherm. Res. 85, 495-515.

Nicholson, K., 1993. Geothermal Fluids: Chemistry and Exploration Techniques. Springer-Verlag, Berlin Heidelberg, Germany.

Nieva, D., Nieva, R., 1987. Developments in geothermal energy in Mexico-part twelve: a catinic geothermometer for prospecting of geothermal resources. Heat Recov. Syst. 7 (3), 243-258.

Okay, A.I., Siyako, M., 1993. The revised location of the İzmir-Ankara Suture in the region between Balıkesir and İzmir (In Turkish). In: Turgut, S. (Ed.), Tectonics and Hydrocarbon Potential of Anatolia and Surrounding Regions. , pp. 333-355.

Okay, A.I., Satır, M., Maluski, H., Siyako, M., Monie, P., Metzger, R., Akyüz, S., 1996. Paleo- and Neo-Tethyan events in northwest Turkey: geological and geochronological constraints. In: Yın, A., Harrison, M. (Eds.), Tectonics of Asia. Cambridge University Press, Cambridge, pp. 420-441.

Özkaymak, Ç., Sözbilir, H., 2008. Stratigraphic and structural evidence for fault reactivation: the active Manisa fault zone, western Anatolia. Turk. J. Earth Sci. $17 / 3,615-635$.

Özkaymak, Ç., Sözbilir, H., Uzel, B., 2011. Geological and palaeoseismological evidence for late Pleistocene-Holocene activity on the Manisa Fault Zone, western Anatolia. Turk. J. Earth Sci. 20, 1-26.

Pamukçu, O., Gönenç, T., Sındırgı, P., Baba, A., 2014. Alication of geophysical methods in gulbahçe geothermal site, urla, izmir, geothermal systems and energy resources: Turkey and Greece. In: Baba, A., Bundschuh, J., Chandrasekharam, D. (Eds.), Series: Sustainable Energy Development, 7. CRC Press, pp. 251-257.

Ring, U., Susanne, L., Matthias, B., 1999. Structural analysis of a complex nape sequence and late orogenic basins from the Aegean Island of Samos, Greece. J. Struct. Geol. 21, 1575-1601.

Roberts, S.C., Jackson, J.A., 1991. Active normal faulting in central Greece: an overview. In: Roberts, A.M., Yielding, G., Freeman, B. (Eds.), The Geometry of Normal Faults, 56. Geological Society London, Special Publications, pp. 125-142.

Robertson, A.H.F., Pickett, E.A., 2000. Paleozoic-Early Tertiary Tethyan evolution of melanges, rift and passive margin units in the Karaburun Peninsula (western Turkey) and Chios island (Greece). In: Bozkurt, E., Winchester, J.A., Piper, J.D.A (Eds.), Tectonics and Magmatism in Turkey and the Surrounding Area, 173. Geological Society London, Special Publication, pp. 43-82.

Sengör, A.M.C., Yılmaz, Y., Sungurlu, O., 1985. Tectonics of the Mediterranean Cimmerides: nature and evolution of the western termination of Paleotethys. In: Robertson, A.H.F., Dixon, J.E. (Eds.), The Geological Evolution of the Eastern Mediterranean Geological Society, 17. Special Publications, London, pp. $77-112$.

Şimsek, Ş., Yıldırım, N., Şimsek, Z.N., Karakuş, H., 2002. Changes in geothermal resources at earthquake regions and their importance. Proceedings of Middle Anatolian Geothermal Energy and Environmental Symposium, 1-13.

Şimsek, Ş., 1997. Geothermal potential in northwestern Turkey. In: Schindler, C., Pfister, M. (Eds.), Active Tectonics of Northwestern Anatolia, The Marmara Poly-Project. Vdf Hochschulverlag. AG an der ETH, Zurich, pp. 111-123.

Sözbilir, H., Uzel, B., Sümer Ö, İnci, U., Ersoy, Y.E., Koçer, T., Demirtaş, R., Özkaymak, C., 2008. Evidence for a kinematically linked E-W-trending İzmir Fault and NE-trending Seferihisar Fault: kinematic and paleoseismogical studies carried out on active faults forming the özmir Bay, Western Anatolia. Bull. Geol. Soc. Turkey 2, 91-114.

Sözbilir, H., Sarı, B., Uzel, B., Sümer, Ö., Akkiraz, S., 2011. Tectonic implications of transtensional supradetachment basin development in an extension-paralle transfer zone: the Kocaçay Basin, western Anatolia, Turkey. Basin Res. 23, 423-448.

Tarcan, G., 2002. Geothermal Water Chemistry, Summer Course Note on Earth Science Application in Geothermal. Dokuz Eylul University, pp. 198.

Tonani, F., 1980. Some remarks on the application of geochemical techniques in geothermal exploration. Proceedings of Adv. Eur. Geoth. Res., Second Symposium, Strasbourg, 428-443.

Truesdell, A.H., 1976. Geochemical techniques in exploration (Summary of section III). In: Proceeding of the 2nd United Nations Symposium on the Development and Use of Geothermal Resources, San Francisco, CA, USA, pp. 53-79 (1).

Uzel, B., Sözbilir, H., 2008. A first record of strike-slip basin in western Anatolia and its tectonic implication: the Cumaovası basin as an example. Turk. J. Earth Sci. 17, 559-591.

Uzel, B., Sözbilir, H., Özkaymak, Ç., 2012. Neotectonic evolution of an actively growing superimposed basin in western Anatolia: the inner bay of Izmir, Turkey. Turk. J. Earth Sci. 22 (4), 439-471.

Uzel, B., Sözbilir, H., Kaymakçı, Ç., Kaymakçı, N., Langereis, C.G., 2013. Structural evidence for strike-slip deformation in the İzmir-Balıkesir transfer zone and consequences for late Cenozoic evolution of western Anatolia (Turkey). J. Geodyn. 65, 94-116. 
Uzel, B., Langereis, C.G., Kaymakçı, N., Sözbilir, H., Özkaymak, C., Özkaptan, M. 2015. Paleomagnetic evidence for an inverse rotation history of Western Anatolia during the exhumation of Menderes core complex. Earth Planet. Sci. Lett. 414, 108-125.

White, D.E., 1957. Magmatic, connate, and metamorphic waters. Geol. Soc. Am. Bull. 68 (12), 1659-1682.

White, D.E., 1970. Geochemistry applied to the discovery, evaluation, and exploitation of geothermal energy resources, in United Nations Symposium on Development and Utilization of Geothermal Resources, Pisa. Geothermics 2 (1) 58-80, Special Issue.
Yiğitbas, E., Elmas, A., Sefunc, A., Özer, N., 2004. Major neotectonic features of eastern Marmara region, Turkey: development of the Adapazari-Karasu corridor and its tectonic significance. Geol. J. 39 (2), 179-198.

Yilmaz, Y., Genç, S.C., Gürer, O.F., Bozcu, M., Yilmaz, K., Karacik, Z., Altunkaynak, S., Elmas, A., 2000. When did the western Anatolian grabens begin to develop? In: Bozkurt, E., Winchester, J.A., Piper, J.A.D. (Eds.), Tectonics and Magmatism in Turkey and the Surrounding Area, 173. Geological Society London, Special Publications, pp. 353-384. 